\title{
ARQUEOLOGIA DAS PRÁTICAS MORTUÁRIAS DE GRUPOS TUPINAMBÁ E GUARANI
}

\section{ARCHEOLOGY OF THE MORTUAL PRACTICES OF TUPINAMBÁ AND GUARANI GROUPS}

\author{
Mariana Alves Pereira Cristante ${ }^{1}$ \\ mariana.cristante@gmail.com
}

\begin{abstract}
RESUMO
Este trabalho trata da variabilidade de contextos funerários associados a grupos Tupinambá e Guarani das regiões do Paranapanema, alto Paraná e regiões próximas dos estados de São Paulo e Rio de Janeiro. Fizemos a análise de material cerâmico, contextos funerários, remanescentes humanos, características dos sítios e fontes etnohistóricas, e essas análises combinadas nos trouxeram diversas considerações a serem feitas sobre a interpretação dos contextos, sua variabilidade, as vasilhas funerárias e a relação entre vivos e mortos para esses grupos.
\end{abstract}

Palavras-chave: contextos funerários, grupos Tupinambá e Guarani, cerâmica, remanescentes humanos

\footnotetext{
${ }^{1}$ Museu de Arqueologia e Etnologia da Universidade de São Paulo - MAE-USP.
} 


\section{ABSTRACT}

This research will deal with the variability of funerary contexts associated with Tupinambá and Guarani groups from Paranapanema and Paraná river basins, and regions near of São Paulo and Rio de Janeiro states. We did the analysis of pottery, funerary contexts, human remains, site characteristics and ethnohistorical sources, and these combined analyzes brought us several considerations to be made about the interpretation of contexts, their variability, funerary vessels and the relationship between living and dead for these groups.

Key words: funerary contexts, Tupinambá and Guarani groups, pottery, human remains

\section{ANTECEDENTES DA PESQUISA}

A Antropologia vem demonstrando que a morte, os mortos e as práticas em relação a eles são fundamentais entre os grupos Tupi (Fernandes, 1963; Viveiros de Castro, 1986, 2013). Por isso, pode-se inferir essa importância também entre grupos anteriores ao contato, como é o caso daqueles que habitaram quase todos os sítios analisados em nossa pesquisa. Conhecer os padrões funerários e as práticas em relação à morte é, desse modo, interessante para se poder pensar sobre diversos aspectos dos grupos Tupinambá e Guarani, desde aqueles relativos à organização social até questões simbólicas ligadas à cosmologia.

A despeito da importância da morte, uma arqueologia das práticas mortuárias de grupos Tupinambá e Guarani ainda engatinha no Brasil. Talvez o baixo número de contextos funerários, e menor número ainda de boas descrições dos mesmos, e a má preservação dos remanescentes humanos sejam as principais causas para isso, mas a elas pode ser acrescentado um comum desinteresse por esses contextos, que leva a investigações pouco aprofundadas sobre esse aspecto da cultura. 
E isso é surpreendente também porque os modelos de origem e expansão Tupi, e as considerações sobre as relações entre esses grupos e outros - como os da chamada Tradição Policroma da Amazônia - foram construídos em grande parte com base em material proveniente de contextos funerários. Pois mesmo quando não é conhecido que os artefatos de coleções e acervos de museus são de fato funerários, sabe-se, através das escavações que já foram realizadas em sítios Tupi, que é muito mais provável se encontrar vasilhas inteiras quando essas eram de contextos assim, já que, em geral, não eram totalmente quebradas pelo uso cotidiano e havia uma preservação diferenciada de seu local de deposição por ser um local funerário. De acordo com Almeida (2013), uma das bases para a relação que Lathrap e Brochado fizeram entre grupos Tupi e a Tradição Policroma estava na existência de sepultamentos secundários em urnas tanto nessa tradição quanto na Tupiguarani. Porém, argumentamos que não há sequer algum tipo de comprovação de que os grupos englobados pela Tradição Tupiguarani - desmembrada em Tupinambá e Guarani - tinham o sepultamento secundário em urnas como predominante. Além disso, também não se sabe se os mencionados sepultamentos secundários policromos ou tupiguarani resultaram de gestos funerários e concepções semelhantes.

Pode-se dizer que tradicionalmente, e até os dias atuais, muitas das considerações feitas pela arqueologia de contextos funerários Tupi no Brasil têm tido uma perspectiva do chamado Histórico-Culturalismo, que considera os contextos 
funerários - ou apenas os artefatos que os compõem - como uma possibilidade para se traçar tipologias a partir desses artefatos, com o objetivo de se encontrar culturas, verificar sua dispersão geográfica e sua profundidade temporal. Assim, de acordo com Silva \& Noelli (2017), a Tradição Tupiguarani, como construída pelo PRONAPA (Programa Nacional de Pesquisas Arqueológicas), tinha como uma de suas definições o sepultamento em urnas cerâmicas, e a presença de certos tipos delas, somada à de outros traços, definia um sítio dessa tradição. Portanto, os contextos funerários Tupi eram objeto de interesse apenas como marcadores de certa cultura arqueológica. Com base nisso, vários pesquisadores descreveram urnas funerárias e contextos, descrições essas que utilizamos aqui. No entanto, poucos foram aqueles que fizeram considerações que ultrapassassem a descrição de contextos locais e a busca por grupos culturais através dos vestígios que escavaram. Nossa pesquisa também busca grupos culturais, e tenta ver sua dispersão no tempo e no espaço.

A pesquisa que realizamos foi um primeiro esforço nosso de sistematização de dados para que possamos compreender os padrões funerários desses grupos e sua variabilidade. Não focamos em questões ligadas à organização social, e nem nas complexas concepções em relação à morte e aos mortos, devido às diversas limitações dos dados - ausência de controle cronológico entre os contextos funerários de cada sítio, descrições parcas e incompletas na maioria dos casos, má preservação dos remanescentes humanos, pequeno número de fontes primárias que descrevam sepultamentos de mais de um indivíduo dentro de um grupo. 
Tivemos como enfoque principal a região do rio Paranapanema e alto rio Paraná, em sítios localizados dentro do atual estado de São Paulo. Entretanto, além desses sítios, recolhemos descrições referentes a outros, localizados nos estados de Paraná, Mato Grosso do Sul e Rio de Janeiro. Essa sistematização nos permitiu ver os padrões regionais, as semelhanças e diferenças entre os contextos ao longo do tempo e também no espaço.

Os contextos com os quais trabalhamos foram escavados ou descritos desde a década de 1960 até a de 2000 por vários pesquisadores (Pallestrini, 1969, 1972, 1975; Pallestrini et al., 1982, 1983-84; Chmyz, 1974, 1979, 1983, 1984, 2002; Scatamacchia et al., 1984; Buarque, 2009, 2016; Buarque et al., 2003; Kashimoto, 1992, 2007; Morais, 1997, 1999; Morais e Piedade, 1994; Moraes, 2007; Kunzli et al., 2010; Faccio, 2011), em diversos projetos e com objetivos diferentes, o que dificultou a sistematização, pois havia sítios com diferentes graus de precisão na descrição dos contextos funerários, além desses terem sido escavados e registrados de maneiras diferentes.

A região do atual estado de São Paulo é considerada como um mosaico de confluências, na qual tradições arqueológicas distintas, algumas definidas antes em outras regiões, se encontram. Há a presença de cerâmicas associadas a grupos Macro-Jê (Aratu, Itararé), bem como de cerâmicas relacionadas a grupos Tupi, e as relações entre esses diferentes grupos, tanto espacialmente quanto ao longo do 
tempo, ainda não são bem conhecidas. O que as pesquisas demonstraram até agora é que diversos grupos originários de diferentes regiões foram para São Paulo, tornando essa área repleta de limites regionais (Moraes, 2007; Afonso, 20082009).

Com relação aos sítios ligados a grupos Tupi, aqueles com cerâmica associada aos Guarani já foram encontrados nas bacias dos rios Paranapanema, Santo Anastácio, Aguapeí, do Peixe, e no alto Paraná. E aqueles com cerâmica associada aos Tupinambá estariam desde o litoral até a bacia do rio Tietê e rio Pardo (Kashimoto \& Martins, 2005). No litoral, a fronteira entre Guarani e Tupinambá se daria na região da baía de Paranaguá, no Paraná (Chmyz, 2002). Já na bacia do rio Mogi-Guaçu, Moraes (2007) considera que os conjuntos cerâmicos atestam a presença de grupos distintos do Tupinambá "tradicional”, denominados Tupi do Interior, que teriam, em sua cerâmica, tanto características morfológicas Tupinambá quanto Guarani, com predomínio das primeiras.

$\mathrm{Na}$ região do rio Paranapanema, alguns pesquisadores tradicionalmente consideram que havia apenas grupos Guarani, que teriam gerado os cenários de ocupação Guarani, e que a fronteira com grupos Tupinambá teria ocorrido a norte desse rio, na bacia do médio Tietê (Morais, 1999; Chmyz, 2002; Afonso, 2006; Faccio, 2011). Porém, de acordo com Noelli (1993) e Corrêa (2014), a região da bacia do Paranapanema teria sido habitada não apenas por grupos Guarani, mas também Tupinambá. Nossas pesquisas vieram a corroborar com essa hipótese, 
pois foram encontradas diferenças significativas que relacionam cerâmicas com padrões de práticas funerárias distintos, como também diferenças nas áreas de implantação dos sítios e na espacialidade dos contextos. Essas distinções, tanto nas morfologias cerâmicas quanto no uso de vasilhas e nos contextos funerários, ocorrem juntamente com continuidades, demonstrando diferenças e semelhanças, continuidades e descontinuidades entre práticas funerárias de grupos Guarani e Tupinambá.

\section{MATERIAL E MÉTODOS}

Nosso levantamento reuniu pesquisas que trabalharam com 119 contextos funerários presumidos, de 35 sítios e ocorrências arqueológicas. Embora nem todos os contextos contivessem ossos humanos preservados, a sua similaridade com contextos funerários já conhecidos levou os pesquisadores a os considerarem funerários. Desses sítios e ocorrências, 17 tiveram seu material cerâmico e ósseo (que encontramos) analisado, 49 vasilhas inteiras e 9 indivíduos. Dos outros sítios foram analisadas apenas descrições e fotos, e eles serviram como comparativo para traçar padrões regionais.

Em nossa pesquisa, buscamos fazer uma análise multidimensional dos contextos funerários, que englobasse, de maneira integrada, análise das cerâmicas, ossos, espacialidade de cada contexto, espacialidade dos contextos em cada sítio em que isso era possível, análise das características gerais de cada sítio (área de implantação, padrões de assentamento, cronologia, etc.), e das mudanças 
diacrônicas nas práticas funerárias. Esse método foi baseado na proposta de Montardo \& Noelli (1995-96), e adaptado. O objetivo foi tentar aliar contextos funerários (posição dos ossos, dos acompanhamentos funerários, organização do sepultamento, sexo e idade do indivíduo), com características dos sítios e com uma análise das características morfológicas e de marcas de uso nas cerâmicas, para que assim pudéssemos traçar padrões funerários regionais entre sítios com cerâmicas associadas a grupos Guarani e Tupinambá.

A essa análise, feita a partir do material arqueológico e das descrições, fotos e croquis dos contextos funerários e sítios, se somou a análise de fontes etnohistóricas e antropológicas que nos trouxeram vários aspectos e questões sobre as práticas funerárias dos grupos linguísticos analisados.

\section{FUNDAMENTOS TEÓRICOS}

\section{Arqueologia das práticas mortuárias}

Ribeiro (2007) utiliza o termo Arqueologia das Práticas Mortuárias para enfatizar de maneira mais ampla os estudos arqueológicos das práticas relacionadas à morte. Quando se fala em práticas mortuárias estamos denominando, de um modo geral, qualquer tratamento dado ao corpo morto. Segundo Monteiro da Silva (2005), o termo Arqueologia das Práticas Mortuárias define uma linha de pesquisa adotada para interpretar dados mortuários, informações arqueológicas que remetem às práticas mortuárias, que são as respostas dos vivos em relação à morte. A partir dos remanescentes humanos e seus acompanhamentos funerários, 
bem como da forma de deposição dos mesmos, podemos entender as características técnicas e operacionais do comportamento funerário intra e inter sítios. Os atributos simbólicos ou rituais das práticas funerárias, embora não possam ser completamente recuperados, podem ser inferidos pelo arqueólogo com base em descrições etnográficas e etnohistóricas.

Os vestígios das práticas funerárias constituem traços de um funeral maior, ou de um ritual funerário, e este um traço dos sistemas sociais. Por isso, características de grupos, em especial suas respostas em relação ao fenômeno morte e iminência de desagregação e extinção do grupo, podem ser trazidas pelos arqueólogos como inferências sobre práticas rituais, obtidas de descrições etnográficas. Uma vez em contexto arqueológico, o ritual resulta em uma cultura material funerária com carga simbólica e potencialidades de interpretação. As ações de caráter simbólico traduzidas em atividades rituais - ou seja, as práticas funerárias - atuando no corpo do morto resultam em produtos observáveis no contexto arqueológico. $\mathrm{O}$ estudo das práticas mortuárias consiste na reconstrução de variáveis biológicas (sexo, idade e traços herdados) e de variáveis culturais (localização e morfologia da cova, a forma de processamento do corpo e os acompanhamentos funerários). A identificação dessas duas variáveis, biológica e cultural, define padrões de sepultamento ou programas funerários de uma determinada sociedade em um período de tempo de longa duração (Monteiro da Silva, 2005).

Os contextos funerários devem ser encarados como um cenário de gestos e 
práticas humanas, funerárias ou não, locais plenos de vida em que muitas coisas podem ter ocorrido, e nos quais processos naturais aconteceram e transformaram o contexto (Mendonça de Souza, 2001; Pearson, 2002; Monteiro da Silva, 2005; Andrews \& Bello, 2009; Mendonça de Souza \& Rodrigues-Carvalho, 2013; Rapp Py-Daniel, 2015).

O funeral não deve ser encarado como um ato pontual, mas sim como um evento que pode ser prolongado, em etapas sucessivas, que modificaram e afetaram a cena funerária. Essa consideração amplia as possibilidades de busca e identificação do impacto humano nos lugares dos mortos (Mendonça de Souza, 2001; Mendonça de Souza \& Rodrigues-Carvalho, 2013). Etnograficamente é conhecido que diversos grupos ameríndios, inclusive Tupinambá e Guarani, tinham práticas funerárias que possuíam um período longo de duração, que podia chegar a meses ou anos.

Dependendo do estágio do ritual funerário, o registro arqueológico pode desaparecer quase completamente. Geralmente, em especial em áreas tropicais e de solos ácidos, a preservação de tecidos moles, roupas e acompanhamentos funerários orgânicos é ruim ou nula, dependendo do material e das condições contextuais. Isso dificulta a recuperação dos gestos funerários de muitos contextos. Além disso, nem todas as práticas funerárias deixam um registro arqueológico, e as diferentes práticas não têm uma chance igual de deixar um registro, sendo que algumas o destroem por completo (Chapmam \& Randsborg, 
1981). Um caso típico é o das urnas funerárias: materiais ósseos dentro delas têm, em geral, melhor preservação do que fora, às vezes dando a impressão de que os sepultamentos predominantes de certo local eram em urnas (Rapp Py-Daniel, 2015).

Locais de mortos são lugares dinâmicos, que passam por diversas intervenções durante seu período de utilização. Além desse período, também é preciso se levar em conta que ocorrem ações após o abandono dessas áreas, ou após certas modificações sócio-políticas. Outros grupos poderiam utilizar a área funerária, ou o mesmo grupo poderia voltar a utilizá-la de outras maneiras (Mendonça de Souza, 2001; Mendonça de Souza e Rodrigues-Carvalho, 2013). Além disso, nem todas as ações que aconteceram em uma área mortuária estão diretamente relacionadas ao ritual funerário. Não há nenhuma razão para crermos que tudo o que há nos contextos funerários está relacionada às práticas funerárias ou à morte (Charles, 2005).

Os processos de formação de depósitos mortuários (naturais e culturais) são muito complexos e muito variáveis, e por isso identificar quais processos estão ligados ao ciclo funerário e quais não estão não é assim tão simples. Igualmente, compreender a variabilidade dos contextos funerários e sua relação com a organização social de um grupo pode, por essa razão, ser mais difícil do que aparente. Identificar um ciclo funerário específico - como um sepultamento secundário ou primário - também pode ser bastante difícil dependendo do estado 
de preservação dos remanescentes humanos e do contexto. Quando os ossos estão incompletos ou desarticulados, é difícil avaliar como era o sepultamento original. Talvez seja por isso que alguns arqueólogos normalmente se referem a contextos em que os ossos estão muito desarticulados ou faltando como sepultamentos secundários, sem discutir sobre sua natureza potencialmente complexa (Andrews \& Bello, 2009; Weiss-Krejci, 2005, 2011). Müller \& Mendonça de Souza (2011) consideram a possibilidade de muitos dos sepultamentos em urna dos Guarani, considerados secundários por muitos arqueólogos, serem na verdade primários que foram tão afetados por processos tafonômicos que seu diagnóstico se tornou inviável. Além disso, o termo "sepultamento secundário" se refere a muitos tipos de práticas e programas funerários diferentes, podendo esses sepultamentos terem passado por muitos tipos de gestos, rituais ou não, acidentais ou intencionais (Weiss-Krejci, 2005).

Portanto, acreditamos que considerar a maioria dos sepultamentos em urna de grupos Tupinambá e Guarani como secundários, como é comum ocorrer, seja fazer uma afirmação sem base empírica. Do mesmo modo, fazer separações de grupos culturais utilizando-se dos sepultamentos secundários, associando grupos por causa da simples presença presumida dos mesmos, pode ser problemático porque poderíamos estar associando práticas funerárias muito diferentes. É preciso que uma série de elementos seja comparada para que se possa inferir afinidade entre sítios e sepultamentos. 
As ações humanas que formam os contextos mortuários são constituídas por gestos funerários, gestos pós-funerários, gestos não funerários e gestos extra funerários. Os gestos não funerários são quando não houve um funeral, e sim apenas um descarte do corpo sem fins funerários, como no caso do descarte de corpos de desparecidos políticos mortos por regimes militares. Gestos funerários ocorreram quando houve a intenção de se dar ao morto um destino adequado, um funeral (rápido ou prolongado). Já os gestos pós-funerários são ações intencionais e conscientes relacionadas ao morto, mas com outros objetivos não necessariamente funerários. E gestos extra funerários são aqueles que também não são fruto de um ritual funerário, mas são obra do acaso, sem intenções específicas com relação àquele morto, como a abertura de uma cova posterior ou a perfuração de um buraco para se erguer uma cabana, sem que houvesse conhecimento de que havia um sepultamento naquele local (Weiss-Krejci, 2005, 2011).

Mendonça de Souza e Rodrigues-Carvalho (2013) levantam a necessidade, em contextos brasileiros, de um olhar mais refinado para os contextos funerários, que busque não apenas os remanescentes humanos, como também os gestos funerários. $\mathrm{O}$ contexto não é constituído apenas por materiais palpáveis e com morfologia definida, mas também por diversos outros elementos que só podem ser observados em campo, alguns muito sutis. As práticas que podemos recuperar são poucas quando comparadas com todos os gestos que provavelmente havia, mais as concepções e simbologias (Monteiro da Silva, 2005; Rapp Py-Daniel, 2015), por isso a recuperação do maior número de elementos possível é fundamental. 
No caso dos contextos funerários Tupinambá e Guarani, a análise não pode ignorar os chamados acompanhamentos funerários, os artefatos que acompanham os remanescentes humanos, que podem ser vasilhas que contêm os ossos (urnas cerâmicas), vasilhas colocadas no sepultamento com outras finalidades (vasilhas anexas, tampas), e também podem ser machados de pedra polida, pingentes de conchas, contas de colar, tembetás. Eles são parte integrante do contexto, juntamente com os ossos, compondo um palimpsesto da cena mortuária.

Os acompanhamentos funerários são cuidadosamente selecionados, e podem ter vários significados diferentes. Eles podem ser artefatos cotidianos ou feitos especificamente para o sepultamento. Podem ser consumidos ou destruídos durante os ritos funerários, ou apenas colocados no sepultamento. Podem ter sido selecionados como lembranças da pessoa sepultada. Vasilhas de acompanhamento podem conter comida ou água, ou estarem no contexto apenas simbolicamente. Os acompanhamentos podem estar próximos ou distantes do morto, e nesse segundo caso é muito difícil a sua recuperação. A recuperação desses aspectos dos acompanhamentos funerários faz parte da arqueologia das práticas funerárias. Como muitas informações sobre a simbologia e gestos inevitavelmente faltam para os arqueólogos, o estudo dos acompanhamentos funerários e sua variação nos contextos é sempre um quebra-cabeças com muitas peças faltando (Pearson, 2002). A comparação dos acompanhamentos no mesmo sítio e em sítios diferentes de uma mesma região possibilita a identificação de mudanças nas tradições de oferendas e na organização dos sepultamentos (Monteiro da Silva, 2005). 
Uma compreensão do quanto os objetos podem ou não ser significativos em um contexto funerários passa pelo conhecimento do que há em contextos residenciais e áreas de descarte, daí a necessidade de se integrar dados da arqueologia num todo, sem fazer fragmentações (Rapp Py-Daniel, 2015).

Os gestos pós-funerários também podem ocorrer em um sepultamento, alterando sua estrutura, às vezes bastante. O reconhecimento se houve ou não gestos pósfunerários não é assim tão simples, e às vezes depende de fontes históricas e etnohistóricas (Weiss-Krejci, 2005, 2011). No caso dos contextos funerários Tupinambá e Guarani, as fontes etnohistóricas e antropológicas nos fazem crer que pelo menos alguns contextos funerários poderiam ter passado tanto por gestos funerários quanto pós-funerários.

\section{A variabilidade das cerâmicas funerárias}

Não poderíamos tratar dos contextos funerários Tupinambá e Guarani sem analisar as vasilhas cerâmicas, que são o elemento mais marcante deles. A variabilidade cerâmica, baseada em tipologias, sempre foi utilizada na arqueologia de grupos Tupi no Brasil. No entanto, a análise de variabilidade que fizemos se preocupa mais com a observação de quais materiais estão espacialmente contextual e regionalmente - associados, e levando em consideração sua cronologia, do que com a construção de tipologias. Essa análise possibilita a reconstrução de padrões funerários regionais, que são compostos por 
continuidades e descontinuidades entre as diversas regiões.

De acordo com Silva $(2007,2009)$, o significado da variabilidade nas morfologias dos artefatos é múltiplo, sendo fruto de escolhas que se relacionam com fatores individuais ou socioculturais, e com motivações tanto pragmáticas quanto simbólicas. Na cerâmica dos Asurini do Xingu, a variabilidade se dá por causa de diferentes fatores, como a funcionalidade das vasilhas, a estrutura de ensinoaprendizagem da confecção da cerâmica, a organização social do grupo, sua cosmologia e contingências históricas. Ela possui diferentes significados de ordem prática, social e simbólica. A organização social e a estrutura de ensinoaprendizagem são responsáveis por variações internas na cerâmica, mesmo que um padrão rigoroso seja seguido. A criatividade no emprego da pintura faz com que haja variações nesse aspecto, e contingências históricas, que geram relações interculturais, fazem com que haja outras variações formais. Assim, certos atributos permitem uma menor ou maior variação nos conjuntos artefatuais. E a variabilidade artefatual pode ser um índice de fronteiras e relações sociais, usada para representar e construir identidades.

Ainda sobre a representação de identidades, de acordo com Dias (2007), baseada nos escritos de Lemonier e Leroy-Gourhan, as técnicas são produções sociais que expressam e definem identidades, reafirmando, representando e dando sentido a um mundo socialmente construído de possibilidades e limites. Sistemas tecnológicos são um recurso e um produto de criação e manutenção de um 
ambiente natural e social, simbolicamente construído. A tecnologia pode ser definida como o corpus de artefatos, comportamentos e conhecimentos transmitidos de geração a geração, e utilizados nos processos de transformação e uso do mundo material. Ela é um produto social, e as escolhas tecnológicas são estratégias dinâmicas, relacionadas frequentemente com diferenciação e identidade social. Tecnologia, função e estilo são aspectos inter-relacionados do comportamento, e sinalizam fronteiras sociais e afiliação cultural, que podem ser reconhecidas na cultura material. Grupos vizinhos em geral têm plena consciência de suas escolhas técnicas mútuas, e a ausência de algum traço tecnológico em um dos sistemas pode representar uma estratégia consciente de demarcação de diferenciações sociais. Contudo, esses fenômenos são altamente contextualizados em termos históricos, podendo ter relação com interesses pessoais ou grupais.

A partir dessas considerações, podemos inferir que a produção das vasilhas utilizadas em contextos funerários associados a grupos Tupinambá e Guarani apresentam uma variabilidade que talvez esteja relacionada tanto com motivações práticas (performance desejada, funcionalidade das vasilhas), quanto simbólicas (cosmologia do grupo), quanto questões relacionadas à organização social (estrutura social, relações de ensino-aprendizagem) e contingências históricas. Além disso, as morfologias e tratamentos de superfície das vasilhas funerárias poderiam também trazer escolhas carregadas por diferentes identidades regionais, que mostrariam relações sociais e ao mesmo tempo fronteiras entre grupos. 
Esses grupos poderiam ser os grandes grupos linguísticos Tupinambá e Guarani, e também poderiam ser grupos menores, mais regionais, dentro desses grandes agrupamentos. Essa perspectiva nos foi lançada pela primeira vez por Moraes (2007), que considera grupos Tupi que ocuparam sítios de regiões da bacia do rio Mogi-Guaçu, estado de São Paulo, como diferentes tanto dos Tupinambá do Rio de Janeiro quanto dos Guarani por causa das morfologias de suas cerâmicas. A autora mostra como uma análise mais rigorosa dos conjuntos cerâmicos pode trazer informações sobre grupos regionais dentro desses grandes agrupamentos linguísticos.

Segundo Robrahn-González (1996), a classificação de sítios que considera tradições arqueológicas ou fases como grupos similares apenas com base em análises gerais sobre a cerâmica podem juntar ocupações marcadamente diferentes. Por isso, não é suficiente fazer a classificação de sítios levando-se em conta apenas uma análise superficial da cerâmica, é preciso levar em conta padrões de assentamento, áreas de implantação dos sítios e características específicas de cada conjunto cerâmico.

\section{Marcas de uso nas cerâmicas}

Além da análise da variabilidade do material cerâmico, também realizamos análise das marcas de uso de vasilhas funerárias. Essa análise se concentrou nas marcas de abrasão presentes na superfície interna e externa de várias vasilhas. 
A história de vida de um artefato engloba sua cadeia operatória de produção, os diversos usos que ele adquire enquanto circula pelo grupo que o produziu, sua deposição e transformação em registro arqueológico, seu resgate por arqueólogos ou pessoas da comunidade local, sua transformação em objeto de museu, entre outras coisas (Holtorf, 2002). Com relação aos usos que um artefato tem no grupo em que foi produzido, ou em outros grupos (caso tenha sido trocado, vendido, roubado ou dado), uma forma de se estudar se havia e quais poderiam ser esses usos é através das marcas de uso.

De acordo com Skibo (1992), as marcas de uso são resultantes de processos físicos ou químicos que podem causar adição, exclusão ou modificação do material na superfície ou em subsuperfície do objeto. Mas a alteração pode ocorrer em qualquer momento desde a manufatura do artefato até sua recuperação pelo arqueólogo e também depois disso. As marcas podem ser feitas por processos de uso ou não do artefato, e por agentes humanos e não humanos. Elas são o resultado de fatores ligados à natureza da cerâmica (confecção, forma, queima, densidade, porosidade, tratamento de superfície, resistência) e das atividades humanas realizadas nas vasilhas. Os tipos de marcas deixados por essas atividades também vão variar de acordo com características de quem usou, modo de usar, os tipos de materiais que foram armazenados, o tempo e a frequência do uso e o contexto do uso. 
Muitas referências sobre contextos funerários de grupos Tupi revelam que as urnas funerárias são "reutilizadas", ou seja, antes de serem usadas para sepultar os mortos eram utilizadas como vasilhas para outros fins, como preparar, servir e estocar alimentos. A fim de tesar essa hipótese com as vasilhas da região pesquisada, nos utilizamos de análise de marcas de uso.

\section{Estudos sobre contextos funerários de grupos Tupi-Guarani}

Descrições sobre contextos funerários e urnas existem pelo menos desde o final do século XIX (p.ex. Ambrosetti, 1895). O primeiro autor a sistematizar informações sobre práticas funerárias de grupos Tupi e Tupi-Guarani foi Alfred Métraux (1947, 1979, 2012[1028]). Foi ele o primeiro a apontar relações entre sociedades Tupi-Guarani estudadas por etnólogos no início do século XX e a imagem dos Tupinambá deixada pelos cronistas (Viveiros de Castro, 1986). De acordo com Métraux (2012 [1928]), o sepultamento primário em urna "do mesmo tipo" era característico de grupos Guarani do Paraguai, devido ao grande número de urnas. Mas não é característico de todos os grupos Tupi-Guarani, apenas de grupos Tupinambá, Guarani do Paraguai, Chiriguano e Guarayu. O sepultamento secundário em urnas, de acordo com o que traz o autor, era praticado por grupos Tupi amazônicos, como os Cocama, Omágua e Oyampi (Wayampi).

Métraux sugere que a ausência do sepultamento secundário em urnas tenha sido um elemento incorporado mais recentemente, quando esses grupos Tupi já haviam saído da Amazônia. Portanto, segundo ele, o sepultamento primário em vasilhas 
cerâmicas seria característico de grupos das regiões meridionais (Métraux, 2012 [1928]).

Ele afirma que os Guarani e Tupinambá praticavam sepultamentos dentro e fora de urna, e que ambos não se excluíam um ao outro, ou seja, havia a presença dos dois. Ele também afirma que havia uma preocupação em não deixar a terra pesar sobre o corpo, e que as urnas possuíam a função de não deixar isso acontecer. Outro tipo de sepultamento, chamado pelo autor de "câmaras funerárias", também possuiria essa função. Tratava-se de se abrir uma cova e cobrir suas paredes com galhos, ou então cobrir o corpo fletido com galhos, de maneira que a terra não o tocasse (Métraux, 2012 [1928]).

Essa questão do peso da terra sobre o corpo, e a simplicidade com a qual Métraux atribui funções para vasilhas cerâmicas (urnas e tampas) funerárias, ignorando os possíveis significados e simbologias envolvidas no emprego dessas vasilhas, foram alvo de críticas. Carvalho (1983) e Mano (2009) sublinham que apenas proteger o corpo da terra não pode ter sido a única função das vasilhas cerâmicas, e que as mesmas possuíam uma simbologia. Isso certamente é válido, mas mesmo assim o peso da terra sobre o corpo pode ter sido uma questão real e importante entre os Tupinambá e Guarani.

José Vicente César $(1966,1975)$ foi o segundo, depois de Métraux, a fazer uma síntese das práticas funerárias (em especial o sepultamento em urnas) dos grupos 
Tupi, e o último até agora a reunir práticas de todos ou quase todos os grupos do Tronco Tupi. Um de seus focos está em romper com a antiga ideia, ainda corrente na época, de que os sepultamentos em urna são exclusivos ou característicos de grupos falantes de línguas do Tronco Tupi. De acordo com ele, além de não serem exclusivos, sequer são característicos, pois não são praticados nem pela maioria dos grupos. Registros de sepultamento primário em urna há somente para Caiuá (Guarani), Carijó (Guarani), Chané, Chriguano (Guarani), Cocama, Cocamilla, Guaianá, Guarani, Guarayu, Omágua, Pauserna, Tupiniquim e Wayoro. Já sepultamento secundário em urna havia entre os Aicauá, Arupaí, Cocama, Curuaia, Guarani arqueológicos, Juruna, Munduruku, Wayampi, Omágua, Tucuniapé e Xipaia.

No entanto, de acordo com o autor, para os grupos Guarani e Tupinambá, o sepultamento em urnas seria típico sim, embora não seja a única forma de sepultamento existente. Mais ao sul do Brasil e países próximos dessa região as vasilhas empregadas como urnas são, em média, mas não exclusivamente, maiores que as mais ao norte, de grupos amazônicos ou do centro-oeste (Cesar, 1966).

Outros autores que trabalharam a questão das práticas funerárias Tupi foram Carvalho e Mano. Carvalho (1983) propõe que o ato de sepultar alguém em vasilhas cerâmicas confeccionadas para se depositar cauim possui a simbologia de transformar o guerreiro que não morria em batalha em cauim e alimento. Segundo a autora, poucos indivíduos eram sepultados em urnas, e esses indivíduos eram 
guerreiros que fizeram cativos para o ritual antropofágico, vingando-se de vários inimigos. Eles seriam sepultados nas vasilhas e cobertos por outras vasilhas - que já contiveram partes do corpo dos inimigos. Essa reutilização de vasilhas explicaria o porquê das urnas não serem padronizadas, nem feitas "sob medida" para o morto.

Mano (2009), afirma que os Tupinambá e Guarani compartilhavam o mesmo tipo de sepultamento, o que deve ter implicações lógicas para uma determinada visão de mundo em comum. Ele concorda com Carvalho no que se refere ao caráter esporádico do sepultamento em urnas, sendo ele reservado a poucos indivíduos. A confecção demorada das grandes vasilhas cerâmicas as tornaria mais raras e em menor número, por isso os indivíduos sepultados deveriam ter uma importância social maior, sendo certamente homens adultos. As urnas e outras vasilhas utilizadas no sepultamento seriam "reutilizadas" de usos cotidianos, não tendo sido confeccionadas somente para o uso funerário. Também da mesma forma que Carvalho, Mano defende que o sepultamento em urnas tem implicações rituais que se relacionam com o universo mágico-religioso-guerreiro dos Tupi-Guarani. O chefe ou guerreiro que não terminasse seus dias sacrificado pelos inimigos era inumado em um grande vaso de cauim ou chicha, para que ele mesmo fosse devorado pelos deuses canibais no céu, tornando-se assim um imortal. As urnas/panelas seriam um meio de transposição para a consumação canibal pelos deuses, para que o morto se tornasse imortal. 
Assim, o sepultamento em urnas teria relação com concepções a respeito de deuses canibais e com o universo simbólico da antropofagia (Mano, 2009).

Acreditamos que certamente o sepultamento em urnas não possuía simplesmente um caráter utilitário, carregando consigo uma carga simbólica fundamental. As marcas de uso nas vasilhas funerárias, de uma maneira geral, sugerem mesmo outros usos além do funerário, tendo a história de vida das vasilhas abrangido mais do que um tipo de uso. E a proposta da existência de uma relação com o universo da antropofagia também parece plausível, embora essa relação não tenha sido satisfatoriamente provada até agora.

Mas o caráter esporádico ou raro do sepultamento em urnas ainda é uma questão que, a nosso ver, precisa ser melhor trabalhada. Não há dados estatísticos que demonstrem claramente se esses sepultamentos eram esporádicos ou não. Sabemos que sepultamentos dentro e fora de urna conviviam nesses grupos, mas nada sabemos sobre o quanto um era mais ou menos frequente em número que o outro. Além disso, há sempre a questão da amostragem no registro arqueológico: há poucas escavações intensivas de sítios Guarani ou Tupinambá, e mesmo essas não conseguem abranger áreas tão grandes quanto provavelmente seriam as áreas de distribuição desses contextos funerários. A ausência de cemitérios - locais específicos de sepultamentos - entre os Tupi faz com que seja difícil realizar análises estatísticas do número de mortos, então não temos como saber ao certo se realmente havia poucos sepultados em urnas ou se eles ocorriam de maneira tão 
dispersa - e distante das áreas residenciais com concentrações de vestígios arqueológicos - que simplesmente não foram encontrados.

Além dessas questões, há outra, fundamental a nosso ver, que influenciaria no número de sepultamentos em um sítio: a movimentação de pessoas nesses grupos. Sabemos que os Guarani atuais possuem alta movimentação de pessoas, e indivíduos e famílias se deslocam pelo espaço, embora não necessariamente o grupo inteiro se mude. Essa mobilidade não poderia indicar que os sepultamentos ocorriam em vários pontos do território Guarani, o que diminuiria o grau de sua concentração?

Finalmente, a última proposta dos autores da qual discordamos é a de os sepultados em urnas serem apenas guerreiros matadores. A ideia de Carvalho (1983) é anterior à tese de Viveiros de Castro, e Mano seguiu a ideia original da autora de que os poucos sepultados em urnas seriam guerreiros. Mas Viveiros de Castro $(1986,2013)$ afirma que, para os Araweté, os Maï não devoravam os matadores de gente (de inimigos), pois eles já haviam passado pela morte e já eram imortais. Quando iam para o céu, eles não passavam pelo canibalismo divino e iam direto para o banho rejuvenescedor, pois não havia neles mais humanidade que precisasse ser digerida pelos Maï. Segundo o autor, os devorados pelos deuses eram por excelência mulheres adultas, embora fosse difícil que todos ou mesmo a maioria dos homens fossem matadores, mesmo em tempos antigos, então homens também eram devorados pelos deuses. Crianças pequenas também não eram 
devoradas (Viveiros de Castro, 1986). Esse argumento, somado às evidências arqueológicas dos remanescentes humanos (que representam diferentes sexos e idades entre os sepultados em urnas), enfraquece a hipótese de que os sepultados em urnas entre os Tupinambá eram apenas guerreiros matadores. Não que mulheres não pudessem ser matadoras também, e não conhecemos evidências ou discussões sobre isso na bibliografia. Mas se aceitarmos a hipótese de que os guerreiros dos Tupinambá eram similares aos dos Araweté, o argumento de que aqueles que não pereciam em batalha eram oferecidos em "panelas" para serem devorados pelos deuses não se sustenta, pois, de qualquer modo, guerreiros não precisavam mais ser devorados.

Noelli (1993) procura sistematizar informações sobre práticas funerárias de grupos Guarani, com o objetivo de entender padrões funerários, relacionando-os com os contextos arqueológicos. Ele utiliza o termo urna funerária para nomear o recipiente onde foram depositados remanescentes humanos. Considera o termo igaçaba impróprio, pois trata-se de um neologismo utilizado na Língua Geral para designar certos recipientes, pois significa pote em que fazem os vinhos. Entre os Guarani, a cova era chamada de tibi, não havendo um nome para a vasilha funerária enquanto esquife.

Segundo o autor, os sepultamentos eram feitos dentro ou fora das estruturas de habitação. Para ele, os sepultamentos secundários são aqueles realizados dentro de recipientes cerâmicos, enquanto os primários seriam os realizados diretamente na 
terra (talvez em redes ou esteiras) ou aqueles em que um crânio está coberto por um recipiente cerâmico (Noelli, 1993). Entretanto, nós mesmas não encontramos descrições de práticas claras de sepultamento secundário entre grupos Guarani e Tupinambá, exceto a prática do sepultamento secundário de partes do corpo e/ou cabeças dos mortos em campo de batalha que eram levados de volta para a aldeia após enterramento primário e o desaparecimento parcial dos tecidos moles, e lá eram enterrados em um local derradeiro. De acordo com César (1975), há diversos relatos de práticas de sepultamento secundário para grupos amazônicos, e sepultamentos secundários em urnas - e, de fato, muitas das urnas, inclusive as antropomorfas e zoomorfas, encontradas em vários pontos da Amazônia possuem sepultamentos secundários dentro. Mas para grupos Tupinambá e Guarani, encontramos poucos relatos de gestos que sugiram sepultamento secundário. Não há dados estatísticos que possam responder se os sepultamentos em urna eram em sua maioria secundários ou não, e a má preservação dos remanescentes humanos dificulta o diagnóstico do tipo de sepultamento na esmagadora maioria dos casos. Além do mais, há sempre o problema da descrição das fontes, que pode estar incompleta, ocultando outras etapas do funeral ou outros gestos envolvidos com o sepultamento. Os relatos sugerem principalmente sepultamentos primários em urnas entre os Tupinambá e Guarani.

Segundo Noelli (1993), apenas dois contextos funerários até agora foram encontrados dentro de manchas de terra preta, e ambos foram escavados por Igor Chmyz (1971 e 1983). Todos os outros contextos foram encontrados fora delas. 
De acordo com o autor, das 10 classes de vasilhas identificadas por Brochado, Monticelli e Neumann, 9 já foram encontradas em contextos funerários, sendo que apenas o ñamôpyu (tostador de farinhas) não foi encontrado. Isso sugere que os contextos funerários eram repletos de vasilhas utilizadas em atividades cotidianas de cozinhar, armazenar e servir alimentos e bebidas. As classes de vasilhas utilizadas para se colocar os mortos dentro são yapepó (panela), cambuchí açá (talha para armazenar e fermentar bebidas) e cambuchí irirú (vasilha para armazenar água). Em nossas pesquisas percebemos outra classe utilizada como urna, as cambuchí caguabá (recipiente para beber). Já as vasilhas utilizadas para se cobrir os mortos são ñaetá (caçarola para cozinhar alimentos), ñaé apoá (escudela), yapepó (panela), cambuchí (talha para fermentar bebidas), além de cacos de vasilhas. E as vasilhas que eram colocadas juntos do sepultamento, que não eram nem urnas nem tampas (talvez fossem recipientes para se colocar alimentos e bebidas), podiam ser ñaé (prato para servir), ñaembé (prato para servir), cambuchí caguabá (recipiente para beber), cambuchí mîni igôaba (recipiente para beber), cambuchí yarucuaí (recipiente para beber) (Noelli, 1993).

Outra autora que trabalha com a morte Tupi é Rapp Py-Daniel (2015). De acordo com ela, os grupos Tupi da Amazônia apresentam a maior variabilidade de formas de sepultamento e práticas funerárias: sepultamento primário direto, indireto (em rede, cestaria ou urna), sepultamento secundário direto na terra, exocanibalismo, cremação, mumificação, moqueação, distribuição de ossos, guarda de ossos em residência, exposição em rede ou plataforma. De todas as práticas levantadas pela 
autora, apenas o endocanibalismo e o sepultamento secundário múltiplo não apareceram. Um padrão funerário Tupi não existiria. Ela sugere que essa diversidade de tipos de sepultamento pode ser explicada pela variedade de formas organizacionais que os diferentes grupos Tupi possuem, indo de nômades, pequenos núcleos familiares a sistemas clânicos.

\section{CONTEXTOS FUNERÁRIOS ANALISADOS}

Analisamos as descrições de fotos de contextos funerários já escavados, material cerâmico e remanescentes humanos. A análise da cerâmica se concentrou na variabilidade morfológica, tratamentos de superfície e marcas de uso, e a dos ossos em averiguar seu potencial informativo e diagnosticas sexo e idade aproximada da morte (quando isso fosse possível). De alguns sítios conseguimos mais informações, de outros menos, e de alguns contextos não conseguimos praticamente nenhuma.

Os sítios cujo material analisamos e que conseguimos mais informações estão no quadro a seguir. Além desses, há outros cujas informações não tivemos acesso, apenas a material arqueológico.

Fora esses, analisamos material de outros sítios que não obtivemos quase nenhuma informação: Silveira, Lopes, Romanini e Canuto. Há também aqueles sítios cujo material não analisamos, mas que vimos as descrições e fotos. São eles: Morro Grande, Bananeiras, Serrano, São José (Região de Araruama no Rio de 
Janeiro); Franco de Godoy e coleções do noroeste de São Paulo; ocorrência em Salto, leste de São Paulo; Itororó, PR-SE-3 (Pesqueiro Barragem de Rosana), no baixo Paranapanema; Rio Ivinhema I, Alto Paraná 8 e MT-IV-1, no alto Paraná; PR-FI-148 (Caranguejeiras), na região da hidrelétrica de Itaipu; PR-FO-24 (Ilha do Alemão 1), SP-SG-9 (Hotel Uselpa 2), PR-SE-3 (Vitorino 3), PR-NA-1 (Fazenda Água da Fartura), SP-IP-8 (Cemitério do Renato), SP-IP-9 (Cemitério do Espanhol). Além dos sítios, analisamos material de duas ocorrências arqueológicas, uma no município de Piraju e outra no de Rosana, ambos no estado de São Paulo.

Como já mostramos em artigo anterior (Cristante, 2017a), desses sítios cujo material analisamos alguns apresentam material cerâmico relacionado aos Tupinambá (Prassévichus, Fonseca, Salto Grande do Paranapanema, Jango Luiz, Panema, Itaguá e a ocorrência de Piraju), e outros relacionado aos Guarani (Alves/Nunes, Aguinha, Pernilongo, Lagoa São Paulo 2, a ocorrência em Rosana e outros 3 sítios sem descrições, Canuto, Lopes e Romanini). A separação entre ambos, para esses contextos analisados, ocorre na área do município de Piraju, em São Paulo, no médio Paranapanema. Nem todos os sítios foram passíveis de serem classificados como Guarani ou Tupinambá, pois não tivemos acesso nem a fotos de todo o material. Alguns foram classificados pelos pesquisadores que os escavaram, outros não (Quadro 1, Figura 1). 


\begin{tabular}{|c|c|c|c|c|}
\hline Nome do sítio & Local do sítio & $\begin{array}{l}\text { Época da } \\
\text { pesquisa }\end{array}$ & Datações do sítio & Área do sítio \\
\hline Prassévichus & Itaí- SP & Década de 1980 & - & $\begin{array}{l}80.000 \mathrm{~m}^{2} \\
\text { ou } 8 \text { hectares }\end{array}$ \\
\hline Fonseca & Itapeva - SP & $\begin{array}{l}\text { Final da década } \\
\text { de } 1960\end{array}$ & $\begin{array}{l}899 \mathrm{AD}, \\
1190 \pm 120 \mathrm{AP}, 1110 \pm 110 \mathrm{AP}, \\
1100 \pm 100 \mathrm{AP}, 1100 \pm 110 \mathrm{AP}, \\
1076 \mathrm{AP}, 1010 \pm 100 \mathrm{AP}, 970 \pm 100 \\
\text { AP }\end{array}$ & $\begin{array}{l}40.000 \mathrm{~m}^{2} \\
\text { ou } 4 \text { hectares }\end{array}$ \\
\hline Alves & Piraju - SP & Década de 1970 & $\begin{array}{l}1150 \pm 100 \mathrm{AP}, 1021 \pm 100 \mathrm{AP} \\
1020 \mathrm{AP}, 955 \pm 100 \mathrm{AP}\end{array}$ & $\begin{array}{l}40.000 \mathrm{~m}^{2} \\
\text { ou } 4 \text { hectares }\end{array}$ \\
\hline Aguinha & Iepê - SP & $1999-2010$ & $700 \pm 160 \mathrm{AP}$ & \\
\hline Pernilongo & Iepê - SP & $\begin{array}{ll}1999, & 2000, \\
2002, & 2007, \\
2010 & \end{array}$ & $700 \pm 160 \mathrm{AP}$ & \\
\hline Lagoa São Paulo 2 & $\begin{array}{l}\text { Presidente } \\
\text { Epitácio - SP }\end{array}$ & 2010 & & \\
\hline $\begin{array}{l}\text { Salto Grande do } \\
\text { Paranapanema }\end{array}$ & Salto Grande - SP & $\begin{array}{l}\text { Décadas de } \\
1980 \text { e } 1990\end{array}$ & - & \\
\hline Nunes & Piraju - SP & Década de 1980 & - & \\
\hline Jango Luiz & Angatuba - SP & Década de 1960 & $\begin{array}{l}1260 \mathrm{AP}, 980 \pm 100 \mathrm{AP}, 1540 \pm 150 \\
\mathrm{AP}(765 \mathrm{AD}) \mathrm{e} 1076 \mathrm{AP}\end{array}$ & $\begin{array}{l}38.000 \mathrm{~m}^{2} \text { ou } \quad 3,8 \\
\text { hectares }\end{array}$ \\
\hline Panema & $\begin{array}{l}\text { Campina do } \\
\text { Monte Alegre - } \\
\text { SP }\end{array}$ & $\begin{array}{l}\text { Final dos anos } \\
1990\end{array}$ & $\begin{array}{l}290 \pm 40 \text { BP }\left(\text { Beta } n^{\circ} 144862\right) \text { para } \\
\text { o esqueleto; 2030 AP para a } \\
\text { cerâmica }\end{array}$ & - \\
\hline Itaguá & Ubatuba - SP & $\begin{array}{lll}\text { Entre } & 1975 & \mathrm{e} \\
1976 & & \end{array}$ & $660 \pm 80 \mathrm{AP}$ & $\begin{array}{l}580 \mathrm{~m}^{2}, \text { tendo sido } \\
\text { escavados } 342 \mathrm{~m}^{2}\end{array}$ \\
\hline
\end{tabular}

Quadro 1. Distribuição dos sítios, localidade, épocas das pesquisas, datações e áreas em metros quadrados.

Juntamente com essa diferença nas morfologias cerâmicas, estão associadas diferenças na espacialidade dos contextos funerários e, em certa medida, nas áreas de implantação dos sítios. 


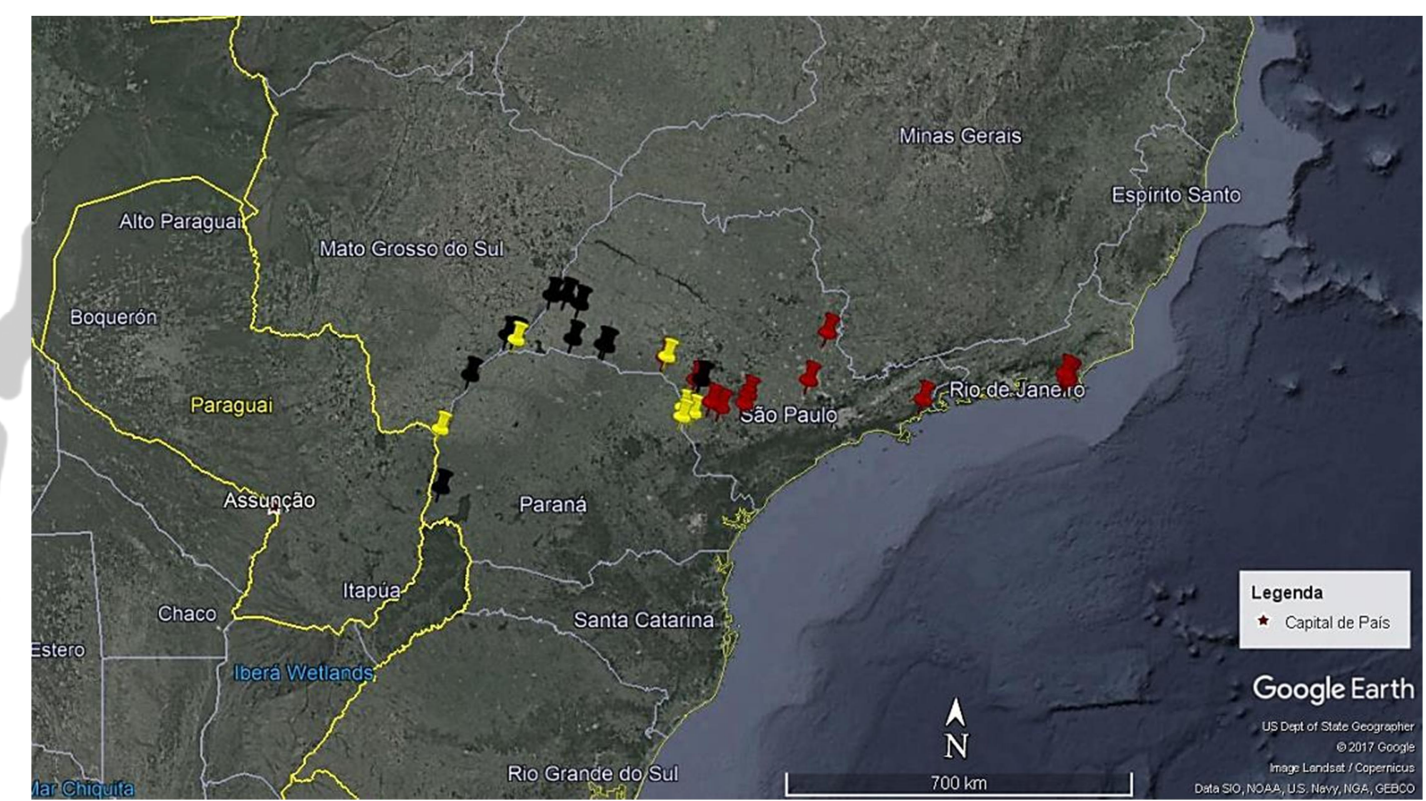

Figura 1: Croqui com a localização dos municípios dos sítios descritos. Legenda das cores: vermelho $=$ sítios com material cerâmico funerário Tupinambá; preto $=$ sítios com material cerâmico funerário Guarani; amarelo = sítios sem classificação do seu material funerário. Elaboração: Mariana Cristante.

Com relação à área de implantação, como já foi escrito por Morais (1999) embora o autor considerasse todos os sítios do Paranapanema como Guarani -, a maioria dos sítios Tupinambá da bacia desse rio analisados se encontra em topo de colina, próximos a rios de menor porte. Quase todos possuem manchas de terra preta, associadas a habitações e uma ocupação prolongada da área. Entretanto, o Salto Grande do Paranapanema tem uma implantação diferente, em terraço fluvial elevado, na calha do Paranapanema e próximo à antiga maior cachoeira desse rio. O sítio Itaguá também é Tupinambá, mas localiza-se no litoral, próximo à praia. Já os sítios Guarani apresentam, em grande parte, um padrão de assentamento 
diferente: em baixa ou média vertente, na calha de um rio de grande porte (ou o Paranapanema ou o Paraná). Vários deles também apresentaram manchas de terra preta. No entanto, o sítio Alves/Nunes, com cerâmicas Guarani, apresenta o mesmo padrão de assentamento que os Tupinambá, em topo de morro e próximo a um rio de menor porte.

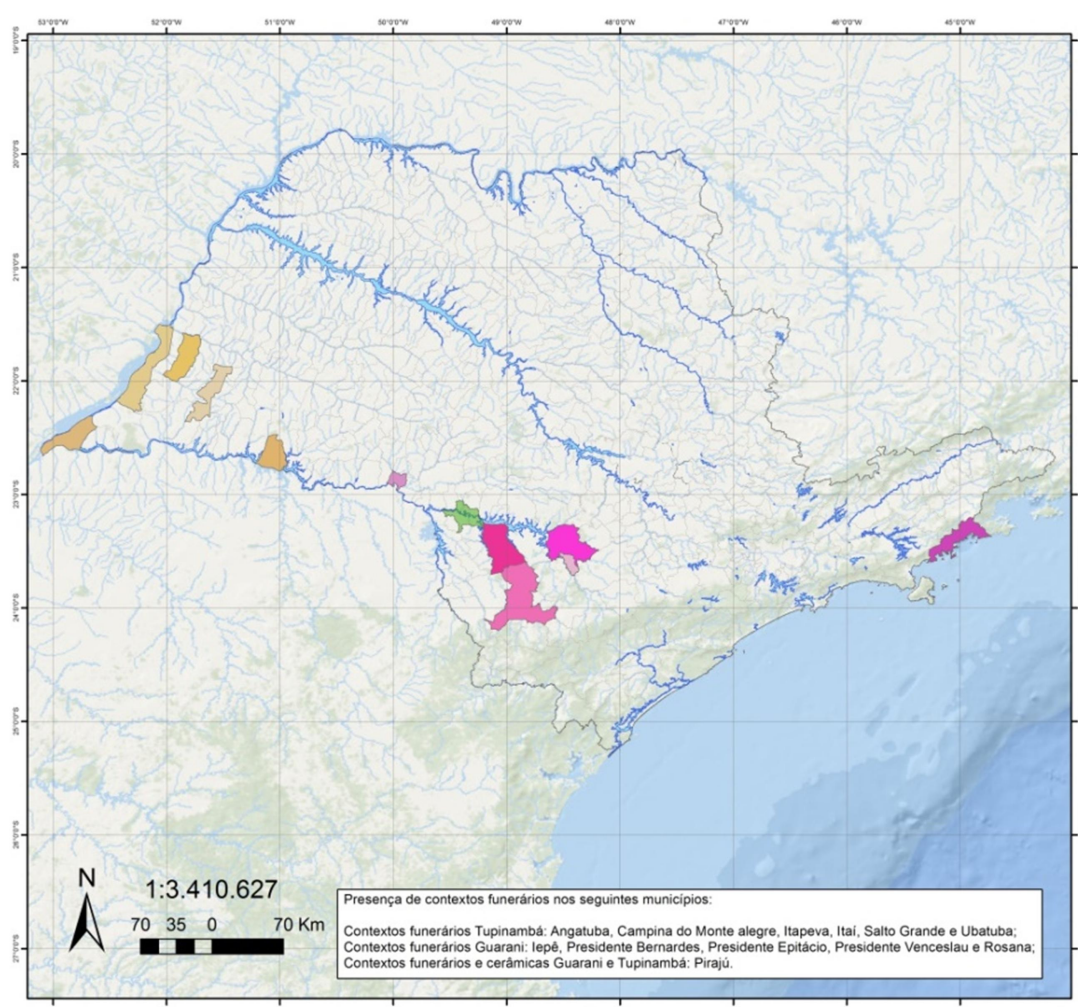

Municípios onde estão os sítios arqueologicos estudados e as ocorrências analisadas
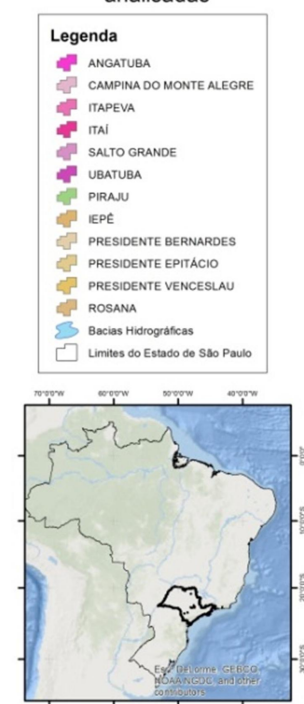

Figura 2: Mapa com os municípios onde aparece material funerário Guarani (castanho) e Tupinambá (rosa). Elaboração: Glauco Constantino Perez. 
Quanto aos períodos de ocupação e datações dos sítios, os sítios Tupinambá analisados são em geral mais antigos que os Guarani, embora outros sítios Guarani do baixo Paranapanema apresentem datas mais antigas (como o sítio Ragil, com 1660 AP). Uma ocupação mais antiga do que certos sítios Guarani para alguns sítios Tupinambá nessa região não é, a nosso ver, algo espantoso, pois há algumas datas antigas para Tupinambá do sudeste (como aquelas mostradas por Buarque, 2009, 2016; ou a data da urna do sítio Panema). Analisando as datações dos sítios, podemos ver tanto sítios Guarani quanto Tupinambá mais antigos e mais recentes nas regiões do estado de São Paulo e seu entorno, o que pode mostrar a movimentação tanto de Guarani quanto de Tupinambá por essa região ao redor do ano mil e mesmo antes, movimentação essa que se prolongou por bastante tempo, até a época do contato e depois.

Um elemento interessante dessa cronologia regional é a contemporaneidade relativa entre um sítio Guarani e um Tupinambá, o Alves e o Fonseca, localizados em áreas não tão distantes entre si do médio Paranapanema. O Alves é o sítio que apresenta padrões funerários mais parecidos com os de sítios Tupinambá da região - a padronização das morfologias das urnas. Essa contemporaneidade e proximidade nos faz inferir que os grupos que os habitavam tinham contato entre si. Agora, a natureza desse contato (se havia uma identificação, se era uma fronteira entre inimigos, entre outras possibilidades) é uma questão a ser trabalhada, pois mais importante, a nosso ver, que dizer se havia identidade entre grupos ou não seria dizer qual poderia ser o significado dessa identidade. Essa 
questão muitas vezes é difícil de ser respondida pelo o arqueólogo (a).

As datações para os sítios não trazem uma cronologia para cada contexto funerário. Um pode ser bem mais antigo que o outro, ou bem mais recente, dentro de um mesmo sítio. Mas é provável que as práticas funerárias do Fonseca e do Alves tenham convivido, assim com as do Aguinha e Pernilongo. E a presença de certos padrões que se repetem em diversos contextos funerários de diferentes sítios com datações variadas nos leva a crer que certos elementos funerários foram preservados e amplamente utilizados, mesmo após muito tempo e em lugares diferentes.

A análise das morfologias e tratamentos de superfície das vasilhas dessa região mostrou padrões funerários diferentes para Tupinambá e Guarani, embora o sepultamento em urna fosse uma constante. Os contextos Tupinambá apresentam urnas funerárias com formato piriforme, com base cônica e bordas diretas sem extroversão. O tratamento de superfície externa é corrugado, ou corrugado mais escovado ou alisado - o que não é um diferencial, estando presente o corrugado em vasilhas de quase todos os sítios analisados. As urnas dos sepultamentos são muito mais padronizadas entre si dentro do sítio, e também entre os diferentes sítios (embora nem todas sejam piriformes e corrugadas). A urna piriforme corrugada (ou corrugada e alisada, corrugada e escovada) é recorrente inclusive naqueles sítios longe do Paranapanema, da bacia do rio Mogi-Guaçu, do leste de São Paulo e da região de Araruama no Rio de Janeiro. 
No caso do sítio Morro Grande (Tupinambá-RJ), foram obtidas datas

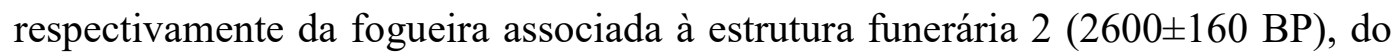
perfil contíguo a essa estrutura $(2200 \pm 70 \mathrm{BP})$, e da própria estrutura $(1740 \pm 90$ BP) (Buarque, 2016). A data do sepultamento pode indicar que, em comparação com os do sítio Fonseca, esse pode ser anterior (embora as datas para o Fonseca não sejam dos contextos funerários). Isso poderia indicar que a diferença se dá por causa de mudanças diacrônicas nas práticas funerárias, que é uma variável que pode causar essa diferença nas práticas.

Já os contextos Guarani possuem urnas com bordas extrovertidas, com morfologias bem diferentes dessas urnas Tupinambá, e que se repetem também em sítios do Paranapanema e alto Paraná. As urnas dentro de cada sítio possuem morfologias e tratamentos de superfície muito mais variados entre si, e entre os vários sítios. A exceção é o sítio Alves, cujas urnas são muito similares entre si, da mesma forma que as dos sítios Tupinambá do alto Paranapanema.

No tocante à espacialidade funerária, os contextos Tupinambá e Guarani do Paranapanema, em especial, apresentaram diferenças significativas. Nos Guarani houve um amplo uso de vasilhas além da urna e tampa, depositadas dentro das urnas, acima ou ao lado. Em alguns desses contextos houve o emprego de grandes vasilhas uma ao lado da outra, com vasilhas dentro; em outros as vasilhas estavam lado a lado com blocos de pedra e tembetá. Já os contextos Tupinambá eram, no alto Paranapanema, em sua maioria, compostos apenas por urna e tampa, sem 
outras vasilhas acompanhando.

Dentro de cada um desses padrões há exceções, contextos com apenas urna e tampa em sítios Guarani, e com duas grandes vasilhas ou urna com vasilhas dentro em sítios Tupinambá. Na região de Araruama alguns contextos contavam com uma urna com vasilhas dentro e em volta, sendo que as vasilhas em volta foram colocadas com sua boca virada para a lateral da urna, padrão que só foi encontrado lá até o momento.

Em relação à espacialidade dos contextos em cada sítio, também houve diferenças entre sítios Guarani e Tupinambá. Nos sítios Guarani os contextos funerários estavam mais próximos entre si, e mesmo os que estavam mais distantes se localizavam em uma área mais restrita do sítio, em relação às manchas de terra preta e à área total demarcada. Já nos sítios Tupinambá, em geral os contextos funerários foram encontrados mais espalhados pela área do sítio, não havendo contextos próximos entre si.

Além dessas diferenças entre sítios Guarani e Tupinambá, também há diferenças significativas entre sítios dentro desses agrupamentos. Entre os sítios Guarani, o sítio Alves apresenta suas urnas funerárias bastante padronizadas, como já foi dito, bastante similares entre si, ao contrário dos sítios Guarani do baixo Paranapanema Aguinha e Pernilongo, que apresentam uma variação morfológica muito maior entre suas urnas. Além disso, enquanto nesses sítios foram 
empregadas vasilhas fora, não somente dentro das urnas, no Alves houve a ocorrência apenas de vasilhas dentro, nenhuma ao lado. Entre os sítios Tupinambá, aqueles do alto Paranapanema não apresentam vasilhas ao lado das urnas, e poucas dentro. Já no sítio Morro Grande, da região de Araruama no Rio de Janeiro, ocorreram vasilhas ao lado e dentro de urnas, com as bocas viradas para a urna.

Além dessas diferenças, também podem ser citado o emprego de vasilhas cambuchí caguabá em um sítio Guarani (Pernilongo) e em outros não, e o emprego de uma nhaen Tupinambá no sítio Itaguá, o que não ocorreu em nenhum outro sítio desse tipo.

Se há diferenças entre as práticas funerárias de sítios Guarani e Tupinambá, e também dentro desses agrupamentos, paralelamente também há semelhanças. Como foi definido para a Tradição Tupiguarani, o sepultamento em urnas é recorrente, embora também haja a possibilidade do sepultamento fora delas. Em todos os sítios analisados a estrutura funerária mínima encontrada constitui-se por urna coberta por tampa. No entanto, tal estrutura básica não se esgota nisso, pois há diversas variações regionais e locais da mesma.

Das vasilhas que servem como urna, tampa ou vasilhas anexas (as outras vasilhas do contexto), são encontradas várias das formas descritas por La Salvia \& Brochado (1989). Das urnas, quase todas são yapepó guaçu (ou nhaempepó) e 
cambuchí (ou camuci), tanto em sítios Tupinambá quanto Guarani. No entanto, foi encontrada uma yapepó myri e uma cambuchí caguabá utilizadas como urnas, e também uma nhaen.

Portanto, um padrão entre os sítios Guarani e Tupinambá do Paranapanema é a presença de urnas yapepó guaçu/ nhaempepó e cambuchí/ camuci em todos os sítios principais, sendo que o número de yapepó/ nhaempepó é, em quase todos os casos, muito superior ao de cambuchí. Mesmo nos sítios e ocorrências dos quais só pudemos encontrar uma urna cada, a maioria das mesmas é também yapepó. A exceção é o sítio Pernilongo, que apresenta diversas morfologias diferentes de urnas.

A análise das marcas de uso que analisamos, em especial marcas de abrasão, nos levou a crer que de fato as vasilhas funerárias, tanto urnas quanto vasilhas anexas, passaram por outros usos além do funerário. São marcas relativas a raspagem ou pancadas de objetos, sugeridas pela abrasão, ou então furos para se passar cordas que impeçam o avanço de uma rachadura, que indicam que, antes de serem usadas para o sepultamento, as vasilhas eram usadas em outras atividades, cotidianas, rituais ou ambas. Outra demonstração dessa utilização de cerâmicas feitas anteriormente para outros fins é a presença de cacos de cerâmica utilizados como tampa, ou a cobertura de "buracos" na parte de baixo ou de cima das urnas com outras vasilhas. Por vezes, quando uma vasilha não dava conta de cobrir devidamente a pessoa sepultada, eram utilizadas duas, o que demonstra a 
importância do gesto de cobrir com cerâmicas.

Assim, a análise das marcas de uso das cerâmicas funerárias traz a tona uma questão fundamental das mesmas: sua história de vida diferenciada quando comparada às vasilhas de uso cotidiano. Walker (2001) propõe que os artefatos de contextos rituais possuem uma história de vida diferenciada daqueles de contextos cotidianos, pois sua deposição final ocorreu por ações integrantes desses rituais. A história de vida dos objetos engloba 4 estágios básicos: produção e distribuição, uso, reutilização e descarte (Skibo, 1999). As vasilhas funerárias dos Tupinambá e Guarani, portanto, possuem uma história de vida com pelo menos 4 estágios: seleção das matérias primas, confecção, uso cotidiano ou em outros rituais, uso funerário.

Apesar do alto grau de fragmentação e má preservação dos remanescentes humanos, foi possível tirar conclusões a respeito dos indivíduos sepultados. A presença de homens, mulheres e crianças encontrados em sepultamentos em urnas nos faz crer que os sepultados eram vários tipos de pessoas, não apenas um tipo (guerreiros), como já dissemos antes.

Um dos sepultamentos, o do sítio Panema, merece maior atenção, devido ao fato de ser um achado bem pouco comum até agora, único para a região. Sua análise foi feita por Piedade \& Soares (2000), e os autores chegaram à conclusão que ossos possuíam uma série de marcas de corte, raspagem e sulcos, assim como diferentes marcas de queima. Isso indica que o esqueleto foi manipulado em 
momentos pós-mortem, e é sugerido que, por um lado, os Guarani realizaram raspagens e cortes com fins rituais e, por outro, os jesuítas queimaram os ossos em praça pública com o objetivo de repreender costumes tradicionais dos indígenas. Foi descartada a hipótese de canibalismo por causa do contexto em que os ossos foram encontrados, reunidos (até ossos pequenos) dentro de uma vasilha. Essas são hipóteses baseadas em pesquisa a fontes etnohistóricas. Nossas próprias pesquisas a fontes etnohistóricas e antropológicas sugerem que esse sepultamento pode ser um exemplo de práticas pós-funerárias, ou seja, gestos que não são necessariamente funerários, mas que tinham outros objetivos. Isso mostra uma ligação dos vivos com os mortos que não cessa com a morte.

Outro elemento intrigante desse sepultamento é a diferença entre as datações da urna e do esqueleto, $290 \pm 40$ BP para o esqueleto e 2030 AP para a cerâmica. Piedade e Soares (2000) consideram o sepultamento como Guarani, mas a morfologia cerâmica sugere que seja um contexto Tupinambá. Entretanto, a situação parece mais complexa, pois é uma cerâmica muito mais antiga que o esqueleto, e como objetos (ou pessoas) enterrados juntos não necessariamente foram produzidos (ou nasceram) juntos, pode-se até levantar a hipótese de a urna ser bastante antiga, e foi usada para sepultamento de um indivíduo muito mais recente, que passou por várias manipulações pós-mortem. Mas como não é comum de se realizar datações de urnas juntamente com esqueletos, não há parâmetros para saber dos possíveis erros. 


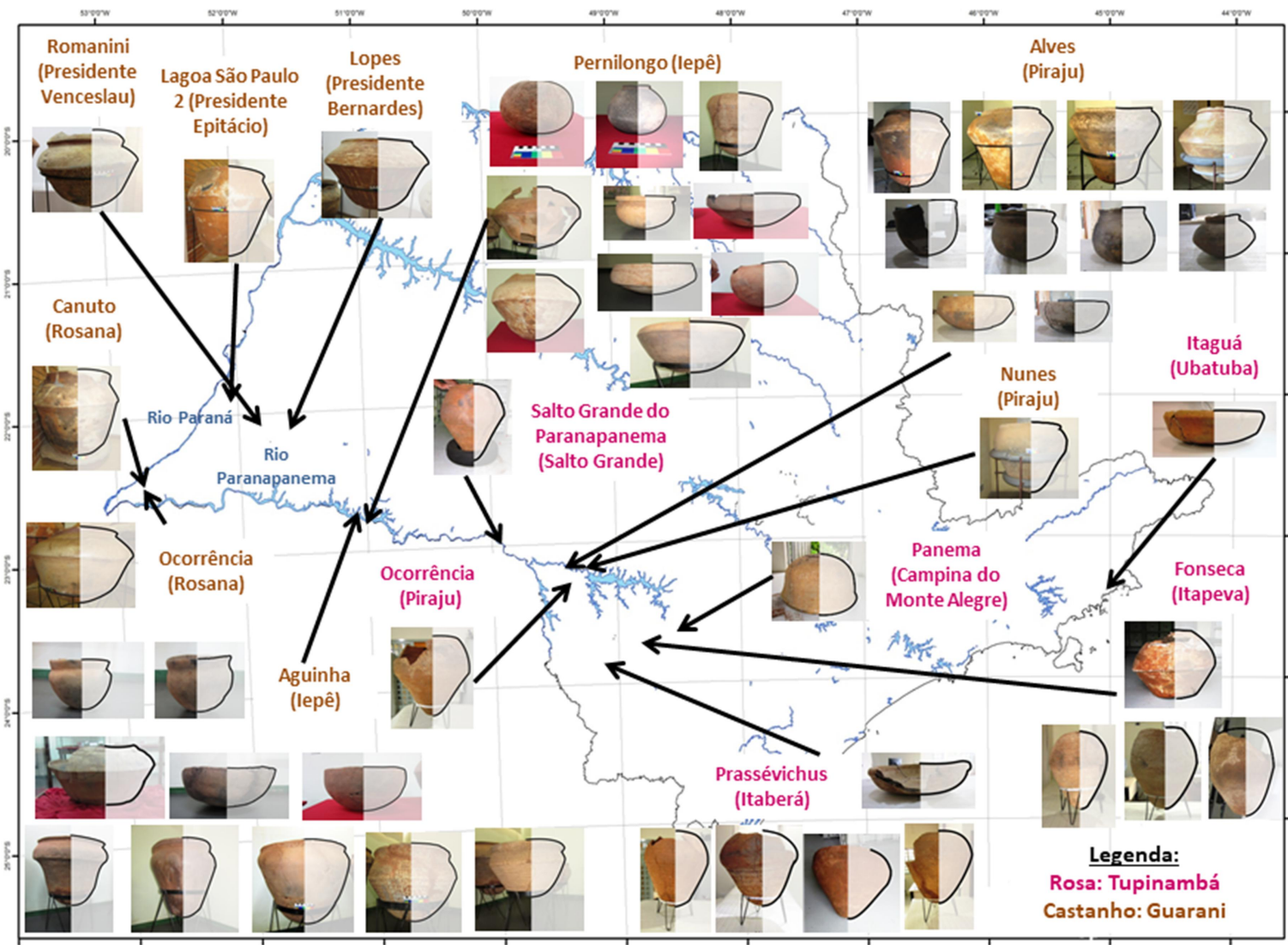

Figura 3: Formas da região do Paranapanema e alto Paraná e sua espacialidade regional.

\section{DISCUSSÃO: POSSIBILIDADES E PROBLEMAS INTERPRETATIVOS DOS CONTEXTOS FUNERÁRIOS}

\section{A variabilidade dos contextos funerários}

Mesmo com todas as dificuldades de sistematização de dados e no lidar com contextos escavados por outros pesquisadores, foi possível tirar várias conclusões 
sobre as práticas funerárias de grupos Guarani e Tupinambá. Essas conclusões devem ser melhoradas com o tempo e pesquisas contextuais mais focadas, nas quais os critérios de análise do contexto e a acurácia das escavações sejam mais rígidos e unificados.

A análise dos contextos funerários e materiais que aparecem neles demonstra que as práticas funerárias dos Tupinambá e Guarani possuem - ao menos nessa região do Paranapanema, alto Paraná, São Paulo e Rio de Janeiro - continuidades e descontinuidades, elementos comuns, similaridades em termos cosmológicos, similaridades nas morfologias de vasilhas em alguns casos, porém, também por elementos distintos, que caracterizam grupos Guarani e Tupinambá (ao menos na região do Paranapanema) e caracterizam diferentes sítios Guarani e Tupinambá. Como se cosmologias com vários elementos comuns estivessem sujeitas a distintas interpretações e manifestações materiais, mas que mesmo assim mantivessem certos padrões.

Igualmente, cerâmicas com morfologias parecidas entre vários sítios - como as nhaempepó do alto Paranapanema, noroeste de São Paulo, município de Salto e município de Araruama no Rio de Janeiro - demonstram que algum tipo de transmissão de conhecimentos, ocorrida em algum momento, levou a essas morfologias parecidas, e o seu emprego funerário certamente fazia parte de uma gama de valores e aspectos simbólicos comuns. Porém, se por um lado as morfologias são muito parecidas, os tratamentos de superfície externa podem 
variar: as do alto Paranapanema analisadas são todas corrugadas; enquanto as do noroeste de São Paulo e do Rio de Janeiro podem ser ou inteiramente corrugadas, ou ter o corrugado associado a outro tratamento (como escovado ou liso).

As fontes etnohistóricas fazem parecer que algumas práticas funerárias, como o sepultamento em urna, são idênticas entre Guarani e Tupinambá. Mas o registro arqueológico parece demonstrar que não o são. Na região do Paranapanema, cerâmicas funerárias estão relacionadas a contextos e a uma espacialidade dos mesmos no sítio, e também a padrões de assentamento, que formam distinções bem marcadas entre os sítios Guarani e Tupinambá. Essas distinções existem paralelamente com as semelhanças (continuidades).

Entre as continuidades, o sepultamento em vasilhas com tampas é uma prática que se repete, sendo uma base entre os gestos funerários tanto de grupos Guarani quanto Tupinambá. A necessidade de se cobrir a cabeça do indivíduo com uma vasilha parece ser um dos fundamentos dessas práticas. A partir dessa base, há as variações nos tipos e morfologias de urnas e tampas. Há também as variações nos contextos funerários, ou seja, nos gestos realizados em relação aos mortos, com a presença ou não de vasilhas anexas.

O levantamento de descrições e fotos de contextos funerários Tupinambá e Guarani trazem alguns tipos de contextos e possíveis contextos funerários que já foram encontrados pela Arqueologia. Não há como saber no momento o 
significado de cada um desses tipos de contextos, se eram realizados para pessoas sociais diferentes ou se eram simplesmente épocas e grupos diferentes. Mas, num mesmo sítio, há diferentes tipos de contextos - apenas urna e tampa, urna com outras vasilhas ao lado, diferentes tipos de urnas -, o que indica que essa variedade se dá no nível local, do sítio (Quadro 2).

\begin{tabular}{|c|c|c|}
\hline $\begin{array}{c}\text { Associados a cerâmica } \\
\text { Guarani }\end{array}$ & $\begin{array}{c}\text { Associados a cerâmica } \\
\text { Tupinambá }\end{array}$ & Associados a ambas \\
\hline $\begin{array}{l}\text { - Contextos em que } \\
\text { remanescentes humanos } \\
\text { sepultados na terra são } \\
\text { acompanhados por } \\
\text { vasilhas próximas; } \\
\text { cambuchí caguabá ou urna } \\
\text { ñaetá com vasilhas dentro } \\
\text { e em volta; } \\
\text { - Contextos compostos } \\
\quad \text { por } \\
\text { urnas com vasilhas } \\
\text { dentro, sobre e/ou em } \\
\text { volta; } \quad \text { Sepultamentos } \\
\quad \text { em } \\
\text { mais de um indivíduo (o } \\
\text { crânio e mais alguns } \\
\text { ossos, ou apenas o crânio) } \\
\text { estava dentro de uma } \\
\text { única vasilha; } \\
\text { - Contextos } \\
\text { cambuchí e/ou yapepó } \\
\text { próximas entre si e outras } \\
\text { vasilhas dentro e/ou em } \\
\text { volta }\end{array}$ & $\begin{array}{l}\text { - Contextos com uma } \\
\text { "cama de argila" sob a } \\
\text { urna; } \\
\text { - Contextos } \\
\text { compostos por } \\
\text { urna, tampa e vasilhas em } \\
\text { volta, posicionadas com a } \\
\text { boca virada para a lateral } \\
\text { da urna; } \\
\text { - Contextos em que } \\
\text { uma } \\
\text { nhaempepó estava } \\
\text { posicionada sobre a outra }\end{array}$ & $\begin{array}{l}\text { Contextos compostos } \\
\text { por } \\
\text { apenas urna e tampa; } \\
\text { - Contextos com duas } \\
\text { ou } \\
\text { mais tampas sobre a urna; } \\
\text { - Contextos com urnas } \\
\text { pequenas demais para se } \\
\text { caber um adulto em } \\
\text { sepultamento primário; } \\
\text { - Contextos em que a } \\
\quad \text { urna } \\
\text { possuía vasilhas apenas } \\
\text { dentro, e não em volta } \\
\text { - Contextos em que } \\
\text { fragmentos de vasilhas } \\
\text { foram usados como tampa; } \\
\text { - Sepultamentos com } \\
\text { materiais trazidos pelo } \\
\text { europeu associados; }\end{array}$ \\
\hline
\end{tabular}

Quadro 2. Associações de contextos nas cerâmicas Guarani e Tupinambá. 
A fragmentação das informações dificulta o diagnóstico de mais diferenças dentro do Tupinambá e do Guarani, mas provavelmente há mais. Se o cenário for de uma base comum na qual certos elementos são interpretados e aplicados de maneira diferente nas práticas funerárias, isso geraria diferenças sutis (ou não tanto) nos contextos funerários.

Essa variabilidade morfológica associada a diferentes línguas nessa região pode ser justificada através dos argumentos de Dias (2007), Silva $(2007,2009)$ e Silva \& Noelli (2017). Escolhas técnicas são produções sociais que expressam e definem identidades, e as técnicas são socialmente aprendidas através de sistemas de ensino-aprendizagem, nos quais a língua pode ser um facilitador e promotor dessa transmissão. Assim, as similaridades entre as cerâmicas de diferentes sítios são fruto de uma transmissão de conhecimentos. Já as diferenças morfológicas mais sutis entre as cerâmicas funerárias dos sítios Guarani e Tupinambá, como as diferenças entre a cambuchí do sítio Alves e as do sítio Pernilongo, por exemplo, seriam fruto de diferentes formas de apropriação desse conhecimento transmitido.

De modo semelhante, o emprego diferenciado de vasilhas funerárias - ou seja, o uso de diferentes tipos de tampa, de diferentes morfologias de urna, diferentes morfologias de vasilhas anexas - pode também estar ligado a variações ligadas a diferentes escolhas relativas à organização social, a fatores de ordem simbólica e prática, e a contingências históricas. Essas variações seriam geradas por modos particulares de se interpretar e proceder com as práticas e rituais funerários. Essas 
interpretações distintas poderiam variar entre os diferentes grupos, submetidos a diferentes histórias. Mas mesmo com todas as variações há uma base comum, tanto dentro do Guarani e do Tupinambá quanto entre ambos.

No sítio Guarani Alves, teriam habitado os mesmos Guarani do Aguinha e Pernilongo, mesmo com as datações alguns séculos mais antigas, e os padrões funerários dos sepultamentos em urna ligeiramente diferentes? E os Tupinambá do Paranapanema seriam os mesmos do Rio de Janeiro? É nesse sentido que acreditamos que as diferenças dentro do Tupinambá e do Guarani poderiam ser pensadas.

\section{As vasilhas funerárias}

As urnas funerárias também são um dos objetos mais abundantes na América do Sul, aparecendo em vários contextos. Entretanto, cada contexto deve ser considerado em suas particularidades. Rapp Py-Daniel (2015) argumenta que os contextos em que elas aparecem são muito diferentes, sendo utilizadas pelos mais diversos grupos, sejam Tupi, Jê, etc. Mas dizer que, por praticarem sepultamento em urna, esses grupos tinham contato, ou que tinham alguma origem comum, não acrescenta muito para a compreensão sobre as diferentes pessoas que possuíam essas práticas funerárias.

Mesmo que as urnas não tenham sido feitas especificamente para uso em rituais funerários, sua confecção certamente previa isso, e esse provavelmente era um dos 
objetivos. Vasilhas foram guardadas para se sepultar os mortos, para dar de comer e beber a eles, para cobrir suas cabeças. Vasilhas velhas, às vezes com fundo quebrado, às vezes rachadas, foram tiradas de uso para serem utilizadas na sepultura, outras vasilhas e fragmentos de vasilhas quebradas foram utilizados como tampa. O uso de aparatos de cozinha nos sepultamentos certamente remete ao que foi proposto por Carvalho (1983) e Mano (2009), sobre um simbolismo que une culinária aos mortos. Entretanto, não sabemos ao certo como era esse simbolismo, nem como ele se relacionava a diferentes tipos de pessoas dentro do grupo.

Apesar de não termos feito um estudo dos conceitos dos Guarani e Tupinambá em relação à morte e aos mortos, nosso levantamento das práticas funerárias já trouxe algumas questões sobre as urnas e vasilhas funerárias que remetem a uma agentividade das mesmas. Embora seja um assunto bem mais amplo e totalmente em aberto, a análise de fontes etnohistóricas permite inferir que essas vasilhas possuíam uma simbologia ligada a aspectos cosmológicos recorrentes entre vários grupos Tupi. Para os Guarani, as vasilhas e tampas tinham o importante papel de impedir que a alma saísse do túmulo para perturbar os vivos, ficando retida na concavidade entre a cabeça e a vasilha. $O$ peso da terra podia ser aliviado através da urna cerâmica. Entre os Guarani e Tupinambá, os alimentos e bebidas colocados em vasilhas na sepultura ou jogados sobre ela tinham o papel de evitar a ação de seres sobrenaturais. A fogueira acendida perto da sepultura tinha esse mesmo objetivo, assim como auxiliar o morto em sua jornada até o paraíso. 
Espíritos eram afastados pelo fogo, alimentados pela comida para que não se alimentassem do morto e não prejudicassem os vivos. O corpo dentro da sepultura possuía uma ligação importante com a alma que estava em sua jornada: esquentando e alimentando o morto, também se esquentava e alimentava a alma.

Pode-se considerar a cerâmica funerária - mas não somente, também outros elementos como fogueiras - como um importante elemento na relação entre os vivos e os mortos entre grupos Tupi-Guarani, que tem o "poder" de impedir que os mortos e espíritos ligados a eles prejudiquem os vivos, e ao mesmo tempo conseguem trazer certos alívios (como do peso da terra) aos mortos e aos vivos com os quais eles tinham relação. Esse importante elemento foi sendo abandonado a medida que os grupos Guarani e Tupinambá foram deixando de produzir cerâmica, e mudanças radicais provocadas pela colonização foram levando a adoção de novos valores e possibilidades, que alteraram drasticamente as práticas funerárias. Entretanto, alguns valores e hábitos ainda se mantiveram.

\section{Contextos funerários e mudanças diacrônicas}

A sistematização de dados sobre os contextos funerários levou à recuperação de contextos inseridos em diferentes épocas, e uma divisão básica pode ser feita:

- Contextos de antes do contato, com sepultamentos em urnas ou fora, associadas a outras vasilhas e ausência de materiais de origem europeia no sítio. Exemplos desses são os contextos funerários do sítio Morro Grande, sítio Aguinha, Alves, Prassévichus, etc. 
- Contextos de período pós-contato, porém temprano, em que há materiais de origem europeia no sítio ou nos próprios contextos, como contas de vidro e fragmentos de metal, mas a estrutura geral não difere dos contextos pré-contato, havendo urnas cerâmicas com tampas e outras vasilhas. Exemplos: sítio Serrano, sítio PR FI 148

(Caranguejeiras).

- Contextos pós-contato em que o uso de vasilhas cerâmicas foi abandonado, havendo mudança inclusive na posição dos corpos sepultados e nas vasilhas com as oferendas. São contextos em que os efeitos do contato já são extremamente significativos na dinâmica do grupo, tendo causado alterações muito grandes nas velhas tradições funerárias, como o caso dos contextos Guarani registrados etnograficamente no século XX.

Essa diferença é uma demonstração material de como os efeitos do contato com o europeu nos grupos indígenas foi decisivo e causou grandes alterações, porém esse contato não se deu de igual maneira em todos os pontos, tendo havido períodos em que certos grupos, apesar do contato, ainda mantinham suas antigas tradições de sepultamento, não tendo sido ainda aldeados, destruídos e obrigados a abandonar seus velhos costumes. Porém, elementos europeus foram incorporados aos contextos funerários. Fruto de escambo, essas contas e pedaços de metal talvez fossem objetos pessoais de prestígio do morto, evidenciado seu uso como um possível marcador de status social de certos indivíduos do grupo. 
Mas com o passar das décadas e dos séculos, cada vez mais grupos tiveram seus antigos costumes e dinâmicas sociais alterados, o que levou a drásticas mudanças nas práticas funerárias.

\section{Gestos pós-funerários em contextos Guarani e Tupinambá}

Embora esse seja um assunto que ainda necessite de mais pesquisas na Arqueologia, as fontes etnohistóricas que lemos já são o suficiente para podermos afirmar que a agência, presença e importância dos mortos entre os vivos entre grupos Tupi, já bastante trabalhada na Antropologia, pode levar a gestos pósfunerários que podem constituir parte dos processos pós-deposicionais sob os quais os contextos funerários estão sujeitos. Por isso, ao se analisar os gostos que possivelmente formaram contextos funerários Tupi, devemos analisar não apenas aqueles que tiveram a ver com o funeral, mas também aqueles que estariam ligados a outros rituais que não o funerários, e que poderiam ser recorrentes devido à importância e presença que os mortos possuem entre os grupos Tupi.

As fontes etnohistóricas apontam para alguns gestos entre grupos Tupinambá e Guarani, como o desenterramento de um morto para lhe quebrar o crânio, e assim realizar o ritual da vingança (gesto feito por indivíduos de outro grupo Tupi, diferente daquele do morto), ou da abertura de sepulturas para a retirada de ossos e manipulação para diversos fins. Consideramos esses tipos de gestos como pósfunerários, devido ao seu caráter não funerário. São gestos em que certos mortos, já sepultados e que provavelmente já passaram pelos rituais funerários, estavam 
envolvidos, mas cujo objetivo não era o de funeral. Os Tupinambá e Guarani abriam a sepultura de inimigos para lhes quebrar o crânio, mas isso não tinha objetivos ligados ao funeral, e sim era para realizar outro ritual, o da vingança. Desse modo, os gestos pós-funerários que possivelmente podem ter ocorrido em contextos ligados a grupos Tupi são aqueles que poderiam também possuir um caráter ritual, mas não de ritual funerário, e sim outros tipos de rituais.

As fontes também falam, entre os Guarani, sobre o desenterramento de ossos de certos indivíduos (alguns xamãs, caciques, crianças pequenas) para serem colocados em outros recipientes (caixas de madeira de cedro, esteiras) em cabanas especiais, para serem com eles realizados rituais e rezas (gestos realizados por indivíduos do mesmo grupo que o morto). Essas práticas de desenterrar seriam gestos pós-funerários ou sepultamento secundário? Ou ambos? Alguns autores, como Cadogan (1968) falam em um sepultamento secundário dos ossos de certos xamãs e caciques, e do sepultamento de crianças que eram primeiro enterradas, depois os ossos retirados, lavados e colocados em uma caixa de madeira de cedro. Embora essa questão ainda precise ser bem melhor trabalhada, argumentamos que, mesmo que sessas práticas configurem um tipo de sepultamento secundário pois há o sepultamento seguido de retirada dos ossos e guarda em outro lugar esses gestos não são uma forma de por um fim à relação com aqueles mortos (ou pelo menos com uma "parte" deles, os ossos) e, além disso, possuem outros objetivos, que não têm a ver apenas com aquele morto, mas que buscam maneiras de trazer benefícios aos vivos. Nesses tipos de gestos, as atitudes que foram 
classificadas como "culto aos mortos" por Cadogan parecem ter sido feitas no sentido de preservar a proximidade com alguns mortos (não com todos), que seriam mortos "especiais", que poderiam trazem benefícios aos vivos.

Além destas, há também a descrição de práticas pós-funerárias não realizadas pelos próprios indígenas, mas pelos padres nas missões, que podiam queimar ossos em praça pública com o objetivo de fazer com que os Guarani parassem de realizar alguns de seus rituais com relação aos mortos, rituais esses que eram abominados pelos catequizadores.

$\mathrm{Na}$ arqueologia de grupos Tupi, questões sobre os processos pós-funerários pelos quais podem ter passado os contextos estão totalmente em aberto. Não se teoriza nem se conhece praticamente nada sobre isso. Mas na interpretação dos contextos, é preciso levar esses processos também em consideração. Dada a importância e presença da morte no mundo dos vivos entre esses grupos, é preciso pensar nos usos, por assim dizer, e nos papéis desses contextos funerários para os grupos envolvidos e também após a partida desses grupos.

As fontes etnográficas sugerem que a morte era uma questão fundamental para os grupos Tupi-Guarani, e que os mortos tinham uma importância e presença muito grandes. Sendo assim, não seria de se esperar uma grande quantidade e recorrência de gestos pós-funerários? O significado da morte Tupi-Guarani e suas relações com o registro arqueológico é um campo que está começando a ser explorado só recentemente. Mas já é possível perceber algumas relações, e que 
elas deixam marcas materiais nos contextos funerários.

\section{CONSIDERAÇÕES FINAIS}

O estudo dos contextos funerários de grupos Guarani e Tupinambá pode ser uma forma de conhecermos outros aspectos dos diversos grupos que falavam essas línguas no passado. Conhecer os mortos desses grupos, os papéis sociopolíticos dos contextos funerários, podem ser um caminho para aprendermos sobre sua importância para as populações do presente, e assim buscarmos formas de manter o respeito por eles.

Em diversas partes do mundo - como nos Estados Unidos, África do Sul e Austrália -, povos indígenas reivindicam há décadas o respeito por suas culturas e seus mortos, discordando da forma como remanescentes humanos são tratados como peças de museu. No Brasil, esse movimento ainda não é muito grande, mas tende a se tornar mais importante a partir dos próximos anos. Por isso, precisamos aprender a lidar com os contextos funerários, seus artefatos e remanescentes humanos, buscando formas de conciliar nossos interesses e nossas pesquisas com os de grupos indígenas. Isso é algo extremamente complexo e difícil, pois contraria todo o nosso modo de fazer pesquisa. Não estamos preparados para lidar com movimentos indígenas querendo, por exemplo, o repatriamento de remanescentes humanos. Mas essa é uma questão que, daqui a alguns anos, pode estar bastante em pauta, e será um problema a ser discutido. 


\section{Agradecimentos}

Agradeço à Prof. Marisa Coutinho Afonso pela orientação e oportunidade. À Prof. Verônica Wesolowski de Aguiar e Santos pela ajuda importante com as análises. Ao Prof. Francisco Noelli pelas orientações e referências bibliográficas. Ao Prof. Sérgio Francisco Monteiro da Silva, pelas orientações e ajuda. À Prof. Neide Barrocá Faccio pela ajuda e orientações, que foram importantes nas análises. Agradeço aos funcionários da biblioteca do MAE/USP (Museu de Arqueologia e Etnologia), em especial ao Hélio, pela ajuda imprescindível, sem a qual eu não teria conseguido encontrar grande parte das referências bibliográficas. À Prof. Ruth Kunzli pela oportunidade de analisar o material no CEMAARQ (Centro de Museologia, Antropologia e Arqueologia), ao Jean Cabrera por toda a ajuda e informações cedidas. Às arqueólogas, arqueólogos e técnicos que realizaram as pesquisas, análises, coletas de dados contextuais, sem as quais essas práticas funerárias estariam perdidas. Agradeço ao Glauco Constantino Perez, pela ajuda com os mapas. À Gabriele Barbosa dos Santos, pela diagramação e ajuda com algumas das imagens, além do constante apoio. À CAPES pela bolsa de estudos. À minha família, pelo constante apoio nessa empreitada, pela força e inspiração.

\section{REFERÊNCIAS BIBLIOGRÁFICAS}

AFONSO, M. C. Um Olhar para a Arqueologia Pré-Histórica do Estado de São Paulo. Tese de livre docência. Museu de Arqueologia e Etnologia, Universidade de São Paulo, São Paulo, Brasil. 2006.

AFONSO, M. C. Um painel da arqueologia pré-histórica no estado de São Paulo: os sítios cerâmicos. Especiaria. Cadernos de Ciências Humanas. Dossiê Arqueologia Hoje, vols. 11 e 12 (20 e 21), 127-155. 2008-2009.

ALMEIDA, F. O. A Tradição Policroma no Alto Rio Madeira. Tese de doutorado. Museu de Arqueologia e Etnologia, Universidade de São Paulo, São Paulo, Brasil.2013. 
AMBrosetTI, J. B. Los Cemeterios Prehistoricos del Alto Paraná (Misiones). Boletin del Instituto Geografico Argentino, tomo 16. 1895.

ANDREWS, P; BELLO, S. Pattern in Human Burial Practice. In: GOWLAND, R; KNÜSEL, C. Social Archaeology of Funerary Remains. Oxford: Oxbow Books. 2009.

BUARQUE, A. Étude de l'occupation Tupiguarani dans la région sud-est de l'État de Rio de Janeiro, Brésil. Tese de doutorado. Institut d'Art et Archéologie, Université Paris 1 Panthéon - Sorbonne, Paris, França. 2009.

As estruturas funerárias das aldeias Tupinambá da região de Araruama, RJ. In:

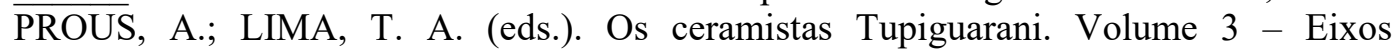
Temáticos. $2^{\mathrm{a}}$ edição. Belo Horizonte: Livraria e Editora Graphar. 2016.

BUARQUE, A.; RODRlGUES-CARVALHO, C.; SILVA, E.C. Programa funerário dos Tupinambá em Araruama, RJ - Sítio Bananeiras. Rev. do Museu de Arqueologia e Etnologia (13), 39-55. 2003.

BUIKSTRA, J. E; UBELAKER, D. H. (eds.). Standards for data collection from human skeletal remains. Arkansas Archaeological Survey Research Series, Arkansas (44). 1994. CADOGAN, L. Chonó Kybwvrá. Aporte al conocimiento de la mitologia Guarani. Revista del Ateneo Paraguayo, Suplemento Antropológico, vol. 3 (1 e 2). 1968.

CARVALHO, S. M. S. A cerâmica e os rituais antropofágicos. Revista de Antropologia vol. 26, 39-52. 1983.

CESAR, J. V. Enterros em Urnas dos Tupi-Guarani. Revista de Antropologia vol. 14, 53 73. 1966.

CESAR, J. V. Igaçabas dos Tupi-Guaranis. Separata dos Arquivos de Anatomia e Antropologia vol. 1, 415-420. 1975.

CHAPMAN, R.; RANDSBORG, K. Approaches to the archaeology of death. In: CHAPMAN, R.; KINNES, I.; RANDSBORG, K. The Archaeology of Death. New York: Cambridge University Press. 1981.

CHARLES, D. K. The Archaeology of Death as Anthropology. In: RAKITA, G. F. M.; 
BUIKSTRA, J. E.; BECK, L. A.; WILLIAMS, S. R. Interacting with the Dead. Perspectives on Mortuary Archaeology for the New Millennium. Florida: University Press of Florida. 2005.

CHMYZ, I. Dados Arqueológicos do Baixo Rio Paranapanema e Alto Rio Paraná. Separata do Programa Nacional de Pesquisas Arqueológicas vol. 26. 1974.

- Projeto Arqueológico Itaipu. Convênio Itaipu-IPHAN. Quarto Relatório das Pesquisas Realizadas na Área de Itaipu (1978/79). 1979.

- Projeto Arqueológico Itaipu. Convênio Itaipu-IPHAN. Sétimo Relatório das Pesquisas Realizadas na Área de Itaipu (1981/83). 1983.

Relatório das pesquisas arqueológicas realizadas nas áreas das usinas hidrelétricas de Rosana e Taquaruçu (1982/3). São Paulo: Cesp.1984.

A Tradição Tupiguarani no litoral do estado do Paraná. Revista do Círculo de Estudos Bandeirantes. Curitiba (16), 71-95. 2002.

CORRÊA, A. A. Pindorama de Mboîa e Îakaré. Continuidade e Mudança na Trajetória das Populações Tupi. Tese de doutorado. Museu de Arqueologia e Etnologia, Universidade de São Paulo, São Paulo, Brasil. 2014.

CRISTANTE, M. A. P. Grupos de línguas Tupi-Guarani no Estado de São Paulo: análise de contextos funerários das bacias dos rios Paranapanema e alto Paraná. Pesquisas, Antropologia (73), 169-191. 2017a.

CRISTANTE, M. A. P. Práticas Funerárias de Grupos de Línguas Tupi-Guarani: Análise de Contextos das Regiões do Paranapanema e Alto Paraná. Dissertação de mestrado. Universidade de São Paulo, Museu de Arqueologia e Etnologia, São Paulo, Brasil. 2017 b.

DIAS, A. S. Novas perguntas para um velho problema: escolhas tecnológicas como índices para o estudo de fronteiras e identidades sociais no registro arqueológico. Boletim do Museu Paraense Emílio Goeldi - Ciências Humanas vol. 2 (1), 59-76. 2007.

FACCIO, N. B. Arqueologia Guarani na Área do Projeto Paranapanema - Os sítios de Iepê. Tese de Livre Docência. Museu de arqueologia e Etnologia, Universidade de São Paulo, São Paulo, Brasil. 2011. 
FERNANDES, F. Organização Social dos Tupinambá. 2a ed. São Paulo: Difusão Europeia do Livro. 1963.

HOLTORF, C. Notes on The Life History of a Pot Sherd. Journal of Material Culture vol. 7 (1), 49-71. 2002.

KASHIMOTO, E. M. Geoarqueologia no baixo Paranapanema: uma perspectiva geográfica de estabelecimentos humanos pré-históricos. Dissertação de mestrado. Faculdade de Filosofia, Letras e Ciências Humanas, Universidade de São Paulo, São Paulo, Brasil. 1992.

O alto curso do rio Paraná: fronteiras ambientais e arqueológicas. Tese de livre docência. Museu de Arqueologia e Etnologia, Universidade de São Paulo, São Paulo, Brasil. 2007.

KASHIMOTO, E. M.; MARTINS, G. R. Uma Longa História em um Grande Rio. Cenários Arqueológicos do Alto Paraná. Campo Grande, MS: Editora Oeste. 2005.

Arqueologia e Paleoambiente do Rio Paraná em Mato Grosso do Sul. Campo Grande: Life Editora, 2009.

KÜNZLI, R. et al. IX Relatório a ser apresentado à CESP, relativo às atividades de campo desenvolvidas em função do contrato CESP/FUNDACTE, visando o pagamento da nona cota. (não publicado). 2010.

LA SALVIA, F.; BROCHADO, J. P. Cerâmica Guarani. Porto Alegre: Posenato Arte e Cultura. 1989.

MANO, M. A Cerâmica e os rituais funerários: xamanismo, antropofagia e guerra entre os tupi-guarani. Interações - Cultura e Comunidade v. 4 (5), 111-128. 2009.

MENDONÇA DE SOUZA, S. A Necrópole Maracá e os Problemas Interpretativos em um Cemitério sem Enterramentos. Boletim do Museu Paraense Emílio Goeldi - Ciências Humanas, Série Antropológica, vol. 17 (2). 2001.

MENDONÇA DE SOUZA, S.; RODRIGUES-CARVALHO, C. 'Ossos no chão': para uma abordagem dos remanescentes humanos em campo. Boletim do Museu Paraense 
Emílio Goeldi. Ciência Humanas, v. 8 (3), 551-566. 2013.

MÉTRAUX, A. Mourning Rites and Burial Forms of the South American Indians. América Indígena vol. 7 (1), 7-44. 1947.

A religião dos tupinambás e suas relações com a das demais tribos Tupiguaranis. São Paulo: Ed. Nacional; Ed. Da Universidade de São Paulo. 1979.

A civilização material das tribos Tupi-Guarani. Campo Grande: Gráfica Editora Alvorada. 2012 [1928].

MONTARDO, D. L. O; NOELLI, F. S. Sugestões para o estudo dos enterramentos Guarani. In: VIII Reunião Científica da Soc. de Arqueologia Brasileira vol. 1 (1), Anais. Porto Alegre: EDIPUCRS, 491-502. 1995-96.

MONTEIRO DA SILVA, S. F. S. Arqueologia das Práticas Mortuárias em Sítios PréHistóricos do Litoral do Estado de São Paulo. Tese de doutorado. Museu de Arqueologia e Etnologia, Universidade de São Paulo, São Paulo, Brasil. 2005.

Arqueologia e Etnografia das Práticas Funerárias: informações sobre o tratamento do corpo em contextos rituais e de morte. Canindé - Revista do Museu de Arqueologia de Xing (11). 2008.

MORAES, C. A. de. Arqueologia Tupi no nordeste de São Paulo: um estudo de variabilidade artefatual. Dissertação de mestrado. Museu de Arqueologia e Etnologia, Universidade de São Paulo, São Paulo, Brasil. 2007.

MORAIS, J. L. Resgate do patrimônio arqueológico da área de influência do Complexo Canoas. São Paulo: Museu de Arqueologia e Etnologia - USP. Relatório USP-CNS 24.1. 1997.

Perspectivas Geoambientais da Arqueologia do Paranapanema Paulista. Tese de Livre Docência. Museu de Arqueologia e Etnologia, Universidade de São Paulo, São Paulo, Brasil. 1999.

. Arqueologia da Região Sudeste. Revista USP (44), 194-217. 2000.

Inventário Progressivo do Patrimônio Arqueológico e Histórico-Arquitetônico dos Municípios do Projeto Paranapanema, Estado de São Paulo. (não publicado). 2001. 
MORAIS, J. L.; PIEDADE, S. C. O homem pré-historico de Salto Grande do Paranapanema. Revista do Museu de Arqueologia e Etnologia vol. 4, 220-222.1994.

MÜLLER, L. M.; SOUZA, S. M. de. Enterramentos Guarani: problematização e novos achados. In: Carbonera, M. e Schmitz, P. I. Antes do Oeste Catarinense - Arqueologia dos Povos Indígenas. Chapecó: Editora da Unochapecó. 2011.

NOELLI, F. S. Sem tekohá não há tekó. Em busca de um modelo etnoarqueológico da aldeia de da subsistência guarani e sua aplicação a uma área de domínio no delta do Rio Jacuí-RS. Dissertação de mestrado. Instituto de Filosofia e Ciências Humanas, Pontifícia Universidade Católica do Rio Grande do Sul, Porto Alegre, Brasil. 1993.

PALLESTRINI, L. Sítio Arqueológico Fonseca. São Paulo: Universidade de São Paulo/ Museu Paulista. 1969.

Supra-estruturas e infra-estruturas arqueológicas no contexto ecológico brasileiro. Revista do Museu Paulista (20), 7-32. 1972.

Interpretação das Estruturas Arqueológicas em sítios do estado de São Paulo.

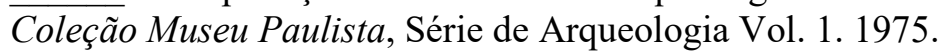

PALLESTRINI, L.; GOULART, M. L.; KNEIP, L. M.; CHIARA, P. MORAIS, J. L. Ensaios de Arqueologia Brasileira vol. 1. Rio de Janeiro: Luna. 1982.

PALLESTRINI, L.; MORAIS, J. L. Prassévichus - aldeia pré-histórica no município de Itaberá - SP. Revista do Museu Paulista (29),151-167.1983-1984.

PEARSON, M. P. The Archaeology of Death and Burial. Texas: A\&M University Press. 2002.

PIEDADE, S.C.; SOARES, A.L.R. Considerações sobre um enterramento Guarani: alterações e hipóteses etno-históricas. Revista do Museu de Arqueologia e Etnologia (10), 31-68. 2000.

RAPP PY- DANIEL, A. Arqueologia da Morte no sitio Hatahara durante a fase Paredão. Dissertação de mestrado. Museu de Arqueologia e Etnologia, Universidade de São Paulo, São Paulo, Brasil, 2009. 
Os Contextos Funerários na Arqueologia da calha do rio Amazonas. Tese de doutorado. Museu de Arqueologia e Etnologia, Universidade de São Paulo, Brasil, 2015.

RIBEIRO, M. S. Arqueologia das práticas mortuárias: Uma abordagem historiográfica. São Paulo: Alameda, 2007.

ROBRAHN-GONZÁLEZ, E. M. Os grupos ceramistas pré-coloniais do centro-oeste brasileiro. Revista do Museu de Arqueologia e Etnologia, São Paulo (6), 83-121, 1996.

SCATAMACCHIA, M. C. M.; UCHÔA, D. P. O contato euro-indígena visto através de sítios arqueológicos do Estado de São Paulo. Revista de Arqueologia (7), 153-173, 1993.

SILVA, F. A. O significado da variabilidade artefatual: a cerâmica dos Asurini do Xingu e a plumária dos Kayapó-Xikrin do Cateté. Boletim do Museu Paraense Emílio Goeldi, Ciências Humanas vol. 2 (1), 91-103, 2007.

- A organização da produção cerâmica dos Asurini do Xingu: uma reflexão etnoarqueológica sobre variabilidade e padronização artefatual. Arqueología Suramericana vol. 5 (2), 121-137, 2009.

SILVA, F.A.; NOELLI, F. S. Arqueologia e linguística: Construindo as trajetórias histórico-culturais dos povos Tupi. Crítica e Sociedade: revista de cultura política, Uberlândia vol. 7 (1), 55-87. Dossiê Povos Indígenas: entre a Antropologia, a Arqueologia e a História, 2017.

SKIBO, J. M. Pottery function: a use-alteration perspective. Interdisciplinary contributions to archaeology. New York: Plenum Press, 1992.

Pottery and People. In: Skibo, J.M.; FEINMAN, G. M. Pottery and People: a dynamics interaction. Foundations of Archaeologycal Inquiry. Salt Lake City: University of Utah Press, 1999.

VIVEIROS DE CASTRO, E. Araweté: os deuses canibais. Rio de Janeiro: Jorge Zahar. 1986.

. O mármore e a murta: sobre a inconstância da alma selvagem. In: VIVEIROS DE CASTRO, E. A Inconstância da Alma Selvagem e Outros Ensaios de Antropologia. $5^{\mathrm{a}}$ ed. São Paulo: Cosac Naify, 181-263, 2013. 
WALKER, W. H. Ceremonial trash? In: SKIBO, J. M.; WALKER, W. H.; NIELSEN, A. E. Expanding Archaeology. Salt Lake City: University of Utah Press, 67-79, 1995.

WALKER, M. H. Ritual Technology in na Extranatural World. In: SCHIFFER, M. B. (ed.). Anthropological Perspectives on Technology. Amerind Foundation New World Studies Series. Book 5. Albuquerque: University of New Mexico Press, 87-106, 2001.

WEISS-KREJCI, E. Excarnation, evisceration and exhumation in Medieval and PostMedieval Europe. In: RAKITA, G. F. M.; BUIKSTRA, J. E.; BECK, L. A.; WILLIAMS, S. R. Interacting with the Dead. Perspectives on Mortuary Archaeology for the New Millennium. Florida: University Press of Florida, 2005.

. The formation of mortuary deposits. Implications for Understanding Mortuary Behavior os Past Populations. In: AGARWAL, S. C.; GLENCROSS, B. A. (eds.) Social Bioarchaeology. Blackwell studies in global archaeology, 2011. 